Article

\title{
Patterns in Protein Components Present in Rattlesnake Venom: A Meta-Analysis
}

\author{
Anant Deshwal ${ }^{1 *}$, Phuc Phan ${ }^{2 *}$, Ragupathy Kannan ${ }^{3}$, Suresh Kumar Thallapuranam ${ }^{2, \#}$ \\ 1 Division of Biology, University of Tennessee, Knoxville \\ 2 Department of Chemistry and Biochemistry, University of Arkansas, Fayetteville \\ 3 Department of Biological Sciences, University of Arkansas, Fort Smith, Arkansas \\ * Correspondence: sthalla@uark.edu \\ * These authors contributed equally to this work
}

\begin{abstract}
The specificity and potency of venom components gives them a unique advantage in development of various pharmaceutical drugs. Though venom is a cocktail of proteins rarely is the synergy and association between various venom components studied. Understanding the relationship between various components is critical in medical research. Using meta-analysis, we found underlying patterns and associations in the appearance of the toxin families. For Crotalus, Dis has the most associations with the following toxins: PDE; BPP; CRL; CRiSP; LAAO; SVMP P-I \& LAAO; SVMP P-III and LAAO. In Sistrurus venom CTL and NGF had most associations. These associations can be used to predict presence of proteins in novel venom and to understand synergies between venom components for enhanced bioactivity. Using this approach, the need to revisit classification of proteins as major components or minor components is highlighted. The revised classification of venom components needs to be based on ubiquity, bioactivity, number of associations and synergies. The revised classification will help in increased research on venom components such as NGF which have high medical importance.
\end{abstract}

Keywords: Rattlesnake; Crotalus; Sistrurus; Venom; Toxin; Association

Key Contribution: This article explores the patterns of appearance of venom components of two rattlesnake genera: Crotalus and Sistrurus to determine the associations between toxin families. This will help us understand the synergistic activities between these components. Synergistic relationship between toxins can be exploited in development of new pharmaceutical drugs.

\section{Introduction}

Venom has become an integral part of the biomedical research[1]. Various venom components have been critical in development new pharmaceutical drugs[2], and possible treatment of diabetes, strokes, heart attacks[3,4], and cancer[5-12]. Venom for most of these researches are sourced from various venomous organisms such as snakes, scorpions, spiders etc. Within snakes, venomous snakes are mainly in three families: Atractaspidae, Elapidae, Viperidae[13]. Despite being just three families the complexity and variability in the venom composition is immense, often being described as a venom cocktail[14-16]. The variation in biochemical composition of snake venom can occur within closely related species and also within species itself[1,17-22]. For example, intra-genus or intra-specific variation in venom in pit vipers and adders $[17,23]$ has been correlated to diet $[17,18,24,25]$ or topographical features[26,27]. One of the primary reasons for high diversity and plasticity in snake venom is due to frequent duplication of toxin-encoding genes and recruitment strategy[28-32] 
followed by functional and structural diversification [1,33-37]. The accelerated rate of venom diversification is supported by the hypothesis that suggests the use of venom for predation $[17,33,38$ 40] and prey digestion supports[17].

Within the North and South American continent, it is suggested that venom of Crotalidae has the highest variation in toxicity with high proteolytic activity[41]. Rattlesnakes are within subfamily Crotalinae, of two genera Crotalus and Sistrurus. They are native to the Americas ranging from southern Alberta, Saskatchewan, and southern British Columbia in Canada to central Argentina. There are approximately 32 species of rattlesnakes within the Crotalus and Sistrurus genus[42]. These snakes are found in a myriad of habitat types ranging from the Sonoran Desert of northwestern Mexico to alpine and cloud forest in central and southern Mexico[42]. They occur from below sea level in desert basins in California to about 4,500 $\mathrm{m}$ in the Transverse Volcanic Cordillera of central Mexico[42]. Mexican Plateau and its fringing mountains have the highest diversity of rattlesnakes [42]. This high variability in the habitat type, altitude, and associated diet types along with a large geographical range allows the rattlesnakes to have high variability in their venom composition.

Rattlesnakes possess a variety of different toxins from 10-20 protein families [7,30,43-45] and may not possess all of them at once. These families are enzymatic proteins such as L-amino Acid Oxidases (LAAO) [30,46-49], Phosphodiesterase (PDE)[50-52], Snake Venom Metalloproteases (SVMP)[53-55], Serine Proteases (SVSP)[47,56-58], Phospholipases (PLA2)[59-62]; or non-enzymatic proteins like Myotoxin a and its homologs[63-66], Bradykinin-Potentiating Peptides and BradykininInhibitory Peptide (BPPs \& BIPs)[30,47,67,68], Disintegrins (Dis)[3,47,48,58,69-71], Cysteine-Rich Secretory Proteins (CRiSPs)[2,48,58,65], and C-Type Lectins (CTL)[30,44,51,72]. It is not uncommon for variation in venom composition within species $[17,23]$. This plasticity and variability of venom gives it a unique advantage in biomedical research.

Despite venom being of high importance in medical research, many problems in researching rattlesnake venoms still persist: lack of venom composition studies for several species, often the rare and geographically inaccessible ones, within the genus Crotalus; high cost associated with venombased studies; high variability in venom composition rendering venom composition studies for all age classes in all populations of rattlesnakes impractical; and sparse data on relationship between various venom components makes it impossible to predict the venom components in any species. This dilemma can be avoided by studying relationship between venom components rather than individual units. For example, within Crotalus polystictus, type and potency of proteins expressed varies with age and sex [51,72-74]. Many venom components discovered, such as LAAO and PDE, have not been explored for possible biomedical applications based on major databases searches[32,75]. However, based on the associations and ubiquity alone, it is evident that they do play a role during envenomation.

These new-found relationships between various protein components in snake venom may play key roles in developing suitable treatments for prevalent diseases. Such relationships between toxins, often termed synergisms, are joint effects of multiple toxins which assert greater effects than sum of individual potencies, thus allows snake venoms to be effective with only a trace amounts of venoms[76,77]. In the current study we conduct a meta-analysis to understand the relationship between various of protein components in Crotalus and Sistrurus' venoms. We also report the frequency with which various proteins are present in Crotalus and Sistrurus' venoms. Using the 
medical relevance, relationship to different protein type and frequency of protein appearance can we classify proteins as major component or minor component in venom.

\section{Result}

Out of 192 studies that were screened, 36 studies that did not meet inclusion criteria and 41 studies that met the exclusion criteria were excluded. Remaining 115 full-text articles are included in the analysis.

\subsection{Venom constituents in Crotalus venom}

We identified compositional venom studies, through both transcriptomic and proteomic technologies, for 30 entries, including species and subspecies, within the genus Crotalus. 46 protein families were present in Crotalus (Table 1). There was no study found regarding the venom composition of nine Crotalus species and sub-species. These protein families could be classified based on ubiquity or relationship with other proteins.

Table 1. Venom components within Crotalus genus

\begin{tabular}{|c|c|c|}
\hline Species & Venom components & Reference \\
\hline C. adamanteus & $\begin{array}{c}\text { 5’NT, BPP, Carboxypeptidase (E-Like), CNP, CRiSP, CTL, } \\
\text { Dipeptidase, Dis, EF-hand protein, EGF, GC, Hya, Kun, } \\
\text { LAAO, MYO, NGF, PDE, PLA2, PLB, SVMP-P I/II/III, SVSP, } \\
\text { VEGF, Vespryn }\end{array}$ & [78-90] \\
\hline C. aquilus & Hya, PLA2, SVMP P-III, SVSP (TLE) & {$[62,72]$} \\
\hline C. atrox & $\begin{array}{l}\text { BIPs, BPPs, CNP, CRiSP, Dis, Hya, LAAO, CTL, PLA2, SVMP } \\
\text { P-I/III, SVSP, VEGF }\end{array}$ & {$[6,47,83,91-98]$} \\
\hline C. basiliscus & $\begin{array}{l}\text { BPP, CRISP, CTL, Dis, LAAO, PLA2 (CRTX, non-CRTX), } \\
\text { SVMP P-I/II/III, SVMP-inhibitor, SVSP }\end{array}$ & [99-102] \\
\hline C. catalinesis & SVSP, SVMP P-III, PLA2 & [43] \\
\hline C. cerastes & $\begin{array}{c}\text { 3FTx, 5’NT, BPP, CRiSP, CTL, Dis, Ficolin, Hya, Kun, LAAO, } \\
\text { MYO, NGF, PDE, PLA2, SVMP P-II/III, SVSP, VEGF, Vespryn, } \\
\text { WAP }\end{array}$ & {$[101,103-105]$} \\
\hline C. durissus & $\begin{array}{c}\text { 3FTx, Achase, Aminopeptidase, Angiogenin, BPP, } \\
\text { Carboxypeptidase, CNP, CRiSP, CTL, CysProt inhibitor, } \\
\text { CysProt, Dipeptidyl Peptidase, Dis, FGF, Fraction 5, Hya, } \\
\text { Kazal, Kun, LAAO, Lipase, MYO, NGF, PDGF, PLA2 (non- } \\
\text { CRTX, CRTX), PLB, PLD, Serpin-like, SVMP inhibitor, SVMP } \\
\text { P-III, SVSP,VEGF, Vespryn, WAP }\end{array}$ & {$[48,67,106-121]$} \\
\hline C. enyo & SVSP, SVMP P-I/III, PLA2 & [43] \\
\hline C. horridus & $\begin{array}{c}\text { 5'-NT, BPP, CNP, CRiSP, Dis, EGF-like, GC, Hya, Kun, LAAO, } \\
\text { MYO, Neurotrophic Factor, NGF, PDE, PLA2, SVMP P-I/III, } \\
\text { SVSP, VEGF, Vespryn }\end{array}$ & {$[29,122,123]$} \\
\hline C. lepidus & $\begin{array}{l}5^{\prime} \mathrm{NT} \text {, CRiSP, CTL, Dis, LAAO, PDE, PLA2, SVMP-P-I/III, SVSP } \\
\text { (TLE, Kallikrein) }\end{array}$ & {$[52,124-126]$} \\
\hline C. mitchelli & LAAO, SVSP, PLA2 (CRTX/MTX) & {$[43,127,128]$} \\
\hline C. molossus & Dis, LAAO, MYO, PLA2, SVMP P-I/III, SVSP (TLE) & {$[61,101,129-133]$} \\
\hline
\end{tabular}




\begin{tabular}{|c|c|c|}
\hline C. oreganus & $\begin{array}{c}\text { ANP/BNP, BPP, CNP, CRiSP, CTL, Dis, Hya, Kun, LAAO, } \\
\text { MYO, NGF, PLA2 (D49), PLA2, SVMP P-II/III, SVSP, VEGF, } \\
\text { Vespryn }\end{array}$ & {$[54,59,60,134-140]$} \\
\hline C. polystictus & $\begin{array}{l}\text { BIPs, CRiSPs, CTL, Dis, GC, Hya, LAAO, NGF, PDE, PLA2, } \\
\text { PLB, SVMP P-I/II/III, SVSP (Kallikrein, TLE), Vespryn }\end{array}$ & {$[51,72]$} \\
\hline C. ruber & CTL, Dis, LAAO, PDE, PLA2, SVMP P-I/III, SVSP (Kallikrein) & {$[43,50,141-146]$} \\
\hline C. scutulatus & $\begin{array}{c}\text { 5'-NT, APase, BPPs, CRiSP, CTL, Dis, Hya, Kun, LAAO, MYO, } \\
\text { NGF, PDE, PLA2 (MTX, non-CRTX), SVMP P-I/II/III, SVSP, } \\
\text { VEGF, Vespryn }\end{array}$ & {$[44,55,66,147-151]$} \\
\hline C. simus & 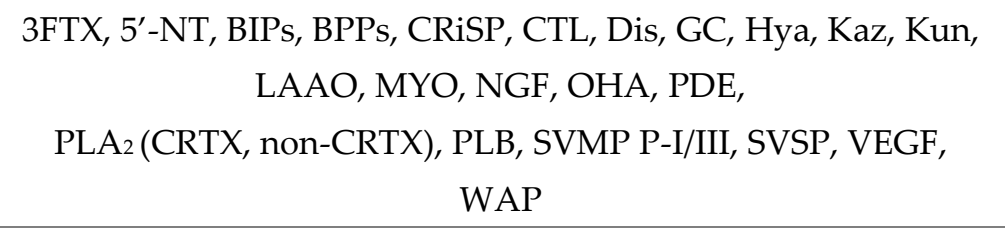 & {$[7,57,71,152-154]$} \\
\hline C. tigris & CRiSP, Dis, PLA2 (MTX), SVMP P-III, SVSP, VEGF & {$[58,155-157]$} \\
\hline C. vegrandis & $\begin{array}{l}\text { 5'-NT, ATPase, BIP, BPP, Carboxypeptidase, CNP, CRiSP, } \\
\text { CTL, Dis, Endonuclease (DNAse, RNAse), Exendin4-like } \\
\text { Protein, Glutathione peroxidase, Hya, LAAO, MYO, NGF, } \\
\text { PDE, PLA2 (CRTX), PLB, SVMP P-II/III, SVSP }\end{array}$ & {$[80,158-162]$} \\
\hline C. viridis & $\begin{array}{c}\text { 5'-NT, APase, BPP, CRiSP, CTL, Dis, GC, LAAO, MYO, OHA, } \\
\text { PDE, PLA2 (CRTX, non-CRTX), PLB, SVMP inhibitor, SVMP P- } \\
\text { I/II/III, SVSP (TLE, Kallikrein) }\end{array}$ & {$[45,63-65,163-166]$} \\
\hline C. willardi & $\begin{array}{l}\text { CRiSP, CTL, Dis, LAAO, PDE, PLA2, SVMP P-I/III, SVSP (TLE, } \\
\text { Kallikrein) }\end{array}$ & {$[52,156]$} \\
\hline C. tortugenesis & N/A & \\
\hline C. stejnegeri & N/A & \\
\hline $\begin{array}{c}\text { C. } \\
\text { tancitarensis }\end{array}$ & N/A & \\
\hline C. lannomi & N/A & \\
\hline C. pusillus & N/A & \\
\hline C. transversus & N/A & \\
\hline C. triseriatus & N/A & \\
\hline C. unicolor & N/A & \\
\hline C. intermedius & N/A & \\
\hline
\end{tabular}

Note: Three-finger toxin (3FTx), 5'-nucleotidase (5'-NT), Acetylcholinesterase (Achase), Natriuretic peptide type A (ANP), Adenosine triphosphatase (ATPase), Bradykinin inhibitory peptide (BIP), Natriuretic peptide type B (BNP), Bradykinin potentiate peptide (BPP), C-type Lectins (CTL), Natriuretic peptide type $\mathrm{C}(\mathrm{CNP})$, Cysteine Protease (CysProt), Cysteine-rich secretory protein(CRiSP), Crotoxin (CRTX), Disintegrin (Dis), Epidermal growth factor (EGF), Fibroblast growth factor (FGF), Guanylyl cyclase (GC), Hyaluronidase (Hya), Kazal-type inhibitor (Kazal), Kunitz-type inhibitor (Kun), L-amino acid oxidase (LAAO), Mojave toxin (MTX), Myotoxin (MYO), Nerve growth factor (NGF), Ohanin (OHA), Phosphodiesterase (PDE), Platelet derive growth factor (PDGF), Phospholipase A2 (PLA2), Phospholipase B (PLB), Phospholipase D (PLD), Snake venom metalloprotease (SVMP), Snake venom serine protease (SVSP), Thrombin-like enzyme (TLE), Vascular endothelial growth factor (VEGF), Waparin (WAP). 


\subsubsection{Frequency of protein components in Crotalus venom}

The ubiquitous protein families in Crotalus venom were: PLA2, SVSP, SVMP P-III, Dis, LAAO, CRiSP, CTL, SVMP P-I, BPP, Hya, and PDE (Figure 1).

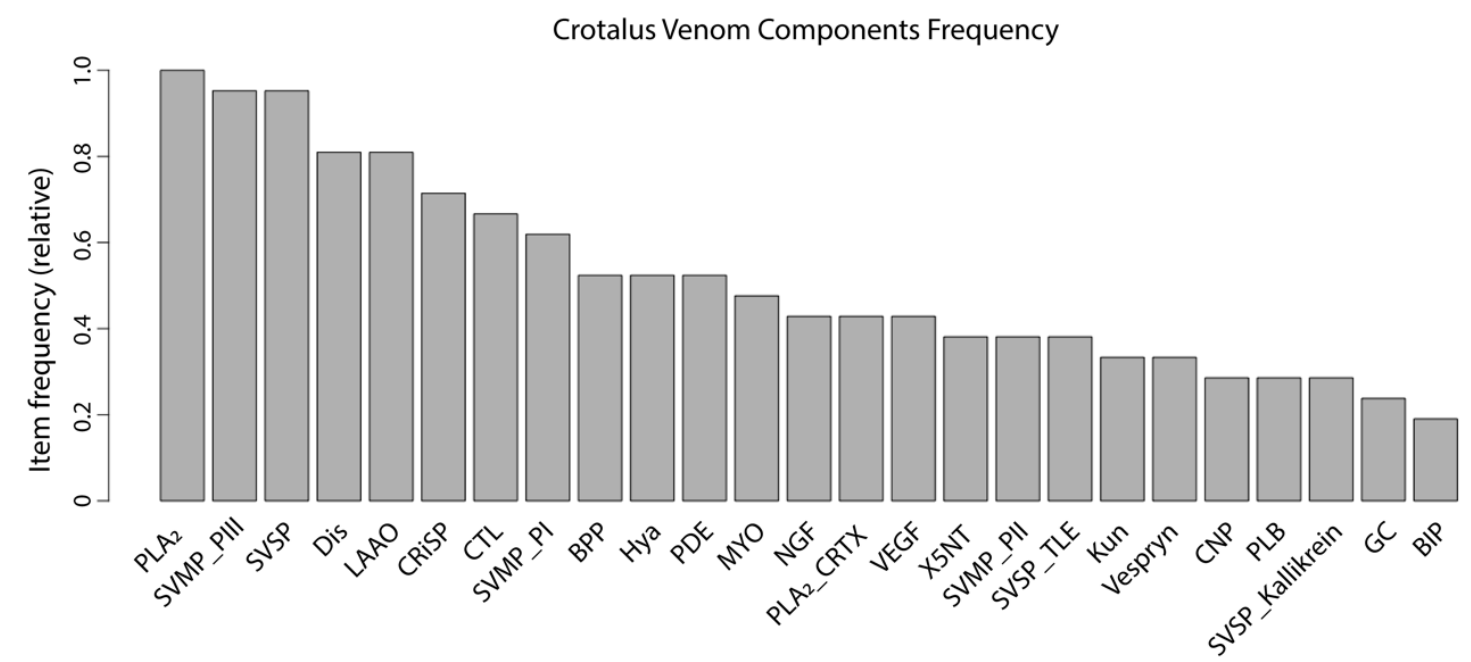

Figure 1. Twenty most common venom components in venom expressed by genus: Crotalus. PLA2 and SVSP are identified as the most common amongst Crotalus species (relative frequency is 1). Note: 5'-nucleotidase (5'-NT), Bradykinin inhibitory peptide (BIP), Bradykinin potentiate peptide (BPP), Ctype Lectins (CTL), Natriuretic peptide type C (CNP), Crotoxin (CRTX), Disintegrin (Dis), Guanylyl cyclase (GC), Hyaluronidase (Hya), Kunitz-type inhibitor (Kun), L-amino acid oxidase (LAAO), Myotoxin (MYO), Nerve growth factor (NGF), Phosphodiesterase (PDE), Phospholipase $\mathrm{A}_{2}\left(\mathrm{PLA}_{2}\right)$, Phospholipase B (PLB), Snake venom metalloprotease (SVMP), Snake venom serine protease (SVSP), Vascular endothelial growth factor (VEGF).

\subsubsection{Association between various venom components in Crotalus venom.}

Using the frequent item-set data mining, we were able to identify total of 559 relationships between different venom components for Crotalus (Table S1) (first three rules did not identify the predictor protein and hence were discarded). In this study we highlight the top 20 associations (Figure 2), e.g., Dis was associated with CTL with confidence $=1$, support $=0.667$ (Table 2). Dis and CTL were expressed together $66.7 \%$ times in venom of all species of Crotalus, and if CTL was expressed in venom, then $100 \%$ times Dis was also expressed. 


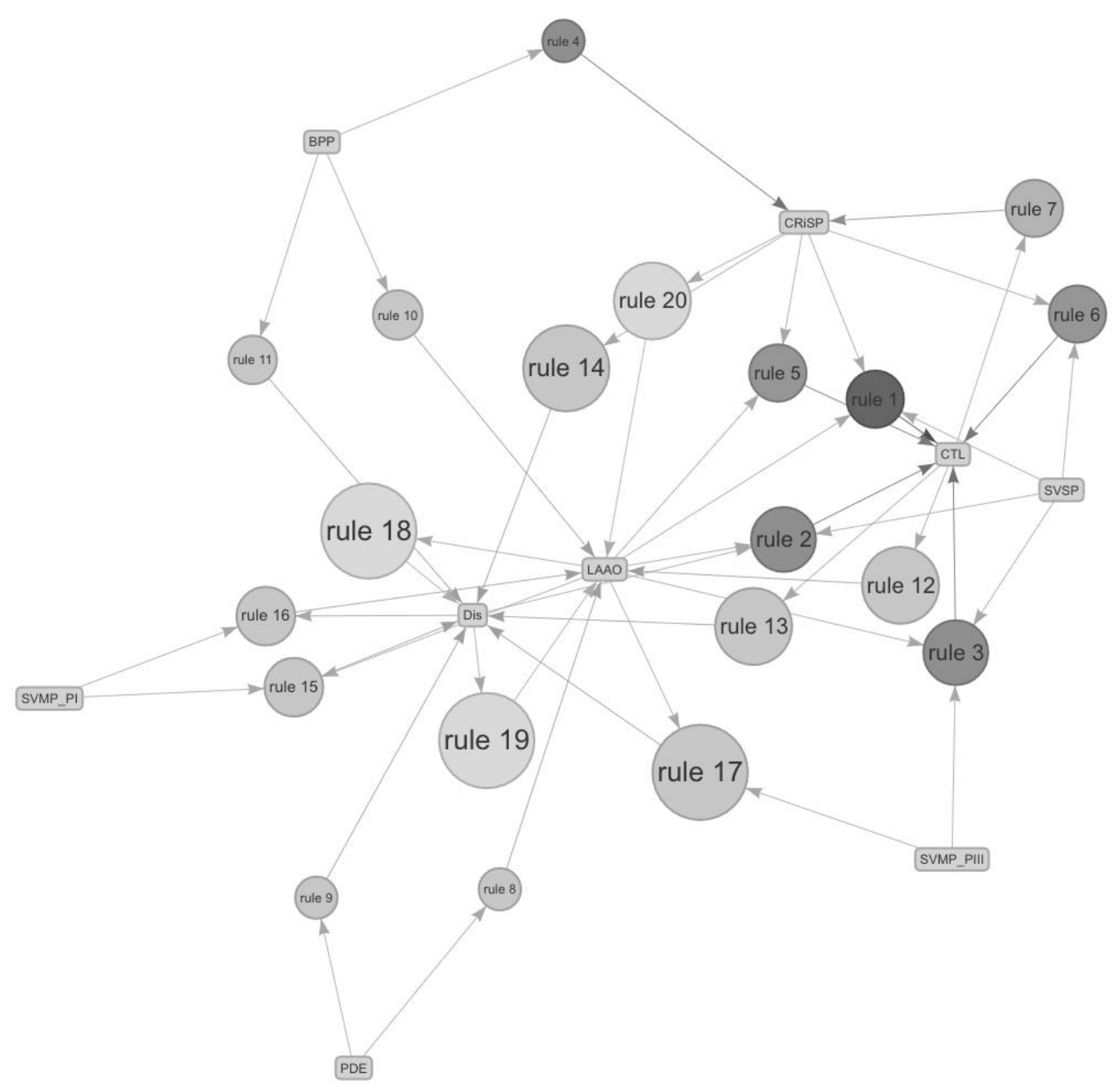

Figure 2. Depictions of association between components of venom expressed by genus Crotalus. The rules are depicted by top twenty minor components-related rules as stated in Table 2.

Table 2. Depictions of association rules between proteins expressed in Crotalus venom.

\begin{tabular}{|c|c|c|c|c|c|}
\hline Rule no. & Protein (Predictor) & $\begin{array}{l}\text { Protein } \\
\text { (Predicted) }\end{array}$ & Support & Confidence & Lift \\
\hline [1] & CRiSP, LAAO, SVSP & CTL & 0.61904762 & 1 & 1.5 \\
\hline [2] & Dis, LAAO, SVSP & CTL & 0.666666667 & 0.933333333 & 1.4 \\
\hline [3] & $\begin{array}{l}\text { LAAO, SVMP P-III, } \\
\text { SVSP }\end{array}$ & CTL & 0.66666667 & 0.93333333 & 1.4 \\
\hline [4] & $\mathrm{BPP}$ & CRiSP & 0.52380952 & 1 & 1.4 \\
\hline [5] & CRiSP, LAAO & CTL & 0.61904762 & 0.92857143 & 1.39285714 \\
\hline [6] & CRiSP, SVSP & CTL & 0.61904762 & 0.92857143 & 1.39285714 \\
\hline [7] & CTL & CRiSP & 0.61904762 & 0.92857143 & 1.3 \\
\hline [8] & PDE & LAAO & 0.52380952 & 1 & 1.23529412 \\
\hline [9] & PDE & Dis & 0.52380952 & 1 & 1.23529412 \\
\hline
\end{tabular}




\begin{tabular}{llllll}
{$[10]$} & BPP & LAAO & 0.52380952 & 1 & 1.23529412 \\
{$[11]$} & BPP & Dis & 0.52380952 & 1 & 1.23529412 \\
{$[12]$} & CTL & LAAO & 0.66666667 & 1 & 1.23529412 \\
{$[13]$} & CTL & Dis & 0.66666667 & 1 & 1.23529412 \\
{$[14]$} & CRiSP & Dis & 0.71428571 & 1 & 1.23529412 \\
{$[15]$} & LAAO, SVMP P-I & Dis & 0.57142857 & 1 & 1.23529412 \\
{$[16]$} & Dis, SVMP P-I & LAAO & 0.57142857 & 1 & 1.23529412 \\
{$[17]$} & LAAO, SVMP P-III & Dis & 0.76190476 & 1 & 1.23529412 \\
{$[18]$} & LAAO & Dis & 0.76190476 & 0.94117647 & 1.16262976 \\
{$[19]$} & Dis & LAAO & 0.76190476 & 0.94117647 & 1.16262976 \\
{$[20]$} & CRiSP & LAAO & 0.66666667 & 0.93333333 & 1.15294118 \\
\hline
\end{tabular}

Note: 5'-nucleotidase (5'-NT), Bradykinin potentiate peptide (BPP), C-type Lectins (CTL), Cysteinerich secretory protein(CRiSP), Disintegrin (Dis), L-amino acid oxidase (LAAO), Nerve growth factor (NGF), Phosphodiesterase (PDE), Phospholipase A2 (PLA2), Snake venom metalloprotease (SVMP), Snake venom serine protease (SVSP).

Crotalus' venom components are studied well enough to generate more than 500 associations, but only the top twenty relevant rules with at least 1 minor components are depicted in Table 2. If Protein (Predictor) is present in venom, then chances of the protein (predicted) to be expressed in the venom is given by combination of confidence and lift. Dis has the highest amount of associations as a predicted component, which is 7: PDE, BPP, CRL, CRiSP, LAAO, SVMP P-I \& LAAO, SVMP P-III \& LAAO. Followed by LAAO with 6 associations: PDE, BPP, CTL, Dis \& SVMP P-I, Dis and CRiSP. On the other hand, CTL is associated with 5 groups and CRiSP represents with 2 associations. However, 5 associations of CTL have higher lifter and confidence than LAAO's and Dis' indicating better associations.

\subsection{Venom constituents in Sistrurus venom}

We identified compositional venom studies, through both transcriptomic and proteomic technologies, for 34 entries, including species and subspecies, within the genus Sistrurus. Few studies have focused on the Sistrurus subspecies' venom. 19 protein families were present in Sistrurus (Table 3). These protein families could be classified based on ubiquity or relationship with other proteins.

Table 3. Venom components within Sistrurus genus

\begin{tabular}{ccc}
\hline Species & Venom components & Reference \\
\hline S. catenatus & 3FTx, 5'-NT, BPP, CNP, CRiSP, CTL, Dis, GC, LAAO, MYO, & {$[29,73,167-172]$} \\
& NGF, PDE, PLA2 (CRTX, non-CRTX), PLB, Renin-like Aspartic & \\
Protease, SVMP P-I/II/III, SVSP, VEGF & \\
\hline S. miliarius & BPP, CRiSP, CTL, Dis, NGF, PLA2, SVMP P-I/III, SVMP- & {$[74]$} \\
miliarius & inhibitor, SVSP & {$[74]$} \\
S. miliarius & BPP, CRiSP, CTL, Dis, NGF, PLA2, SVMP P-I/III, SVMP- & \\
strecker & inhibitor, SVSP & \\
\hline
\end{tabular}




\section{S. miliarius}

BPP, CNP, CRiSP, Dis, PLA2, SVMP P-I/III, SVSP

$[29,30,73,74,172-$

barbouri

Note: Three-finger toxin (3FTx), 5'-nucleotidase (5'-NT), Bradykinin potentiate peptide (BPP), C-type Lectins (CTL), Natriuretic peptide type C (CNP), Cysteine-rich secretory protein(CRiSP), Crotoxin (CRTX), Disintegrin (Dis), Guanylyl Cyclase (GC), Hyaluronidase (Hya), L-amino acid oxidase (LAAO), Myotoxin (MYO), Nerve growth factor (NGF), Phosphodiesterase (PDE), Phospholipase A2 (PLA 2$)$, Phospholipase B (PLB), Snake venom metalloprotease (SVMP), Snake venom serine protease (SVSP), Vascular endothelial growth factor (VEGF).

\subsubsection{Frequency of protein components in Sistrurus venom}

The dominant protein families based on ubiquity in Sistrurus were: BPP, CRiSP, Dis, SVMP, CTL, NGF, PLA2, and SVSP (Figure 3). The main difference between Crotalus and Sistrurus proteins was due to the absence of 27 venom components in Sistrurus (Figure 1, 3). Some of the absent venom components from Sistrurus' proteomic and transcriptomic were: Alkaline phosphomonoesterase (APase), Acetylcholinesterase (Achase), Aminopeptidase, Angiogenin, Natriuretic peptide (ANP and BNP), ATPase, Bradykinin inhibitory peptide (BIP), Platelet-derived growth factor (PDGF), Carboxypeptidase, Cysteine Protease (CysProt) and CysProt inhibitor, Dipeptidase, Dipeptidyl peptidase, EF Hand Protein, Epidermal growth factor (EGF), Exendin4-like protein, Endonuclease (DNAse and RNAse), Fibroblast growth factor (FGF), Ficolin/Veficolin, Glutathione peroxidase, Hyaluronidase (Hya), Kazal-type inhibitor (Kazal), Kunitz-type inhibitor (Kun), Lipase, Ohanin (OHA), Platelet derive growth factor (PDGF), Vespryn, Phospholipase D (PLD), and Waparin (WAP).

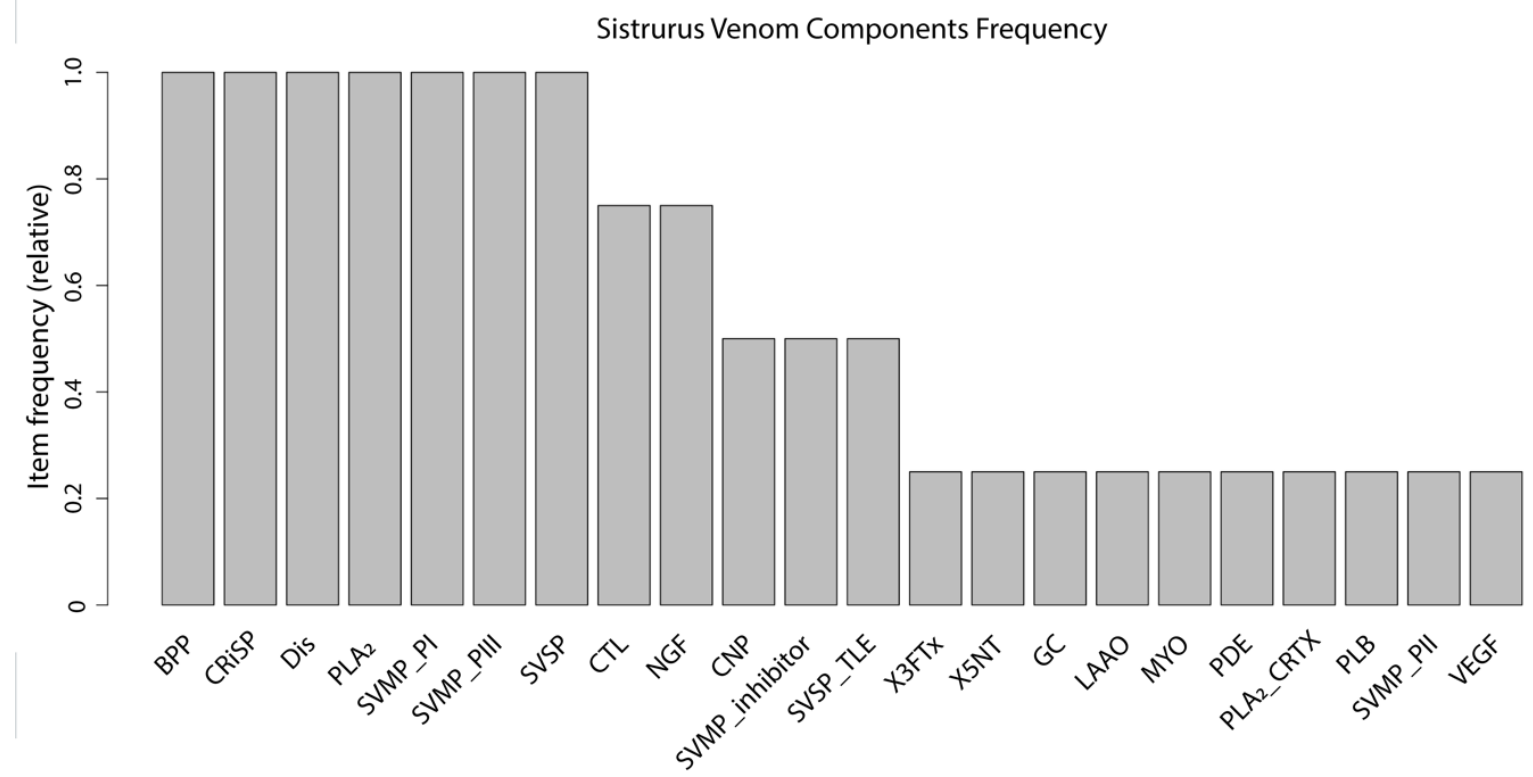

Figure 3. Twenty most common venom components in venom expressed by genus: Sistrurus. BPP, CRiSP, Dis, SVMP P-I/III are the most common toxins (relative frequencies are 1). Note: Three-finger toxin (3FTx), 5'-nucleotidase (5'-NT), Bradykinin potentiate peptide (BPP), C-type Lectins (CTL), Natriuretic peptide type C (CNP), Cysteine-rich secretory protein(CRiSP), Crotoxin (CRTX), Disintegrin (Dis), Guanylyl Cyclase (GC), L-amino acid oxidase (LAAO), Myotoxin (MYO), Nerve growth factor (NGF), Phosphodiesterase (PDE), Phospholipase A2 (PLA2), Phospholipase B (PLB), Snake venom metalloprotease (SVMP), Snake venom serine protease (SVSP), Vascular endothelial growth factor (VEGF). 


\subsubsection{Association between various venom components in Sistrurus venom.}

Using the frequent item-set data mining, we were able to identify eight relationship between different venom components for Sistrurus (Figure 4), e.g., NGF was associated with CTL with confidence $=1$, support $=0.75$ (Table 4 ). NGF and CTL were expressed together $75 \%$ times in venom of all species of Sistrurus, and if NGF was expressed in venom, then $100 \%$ times CTL was also expressed.

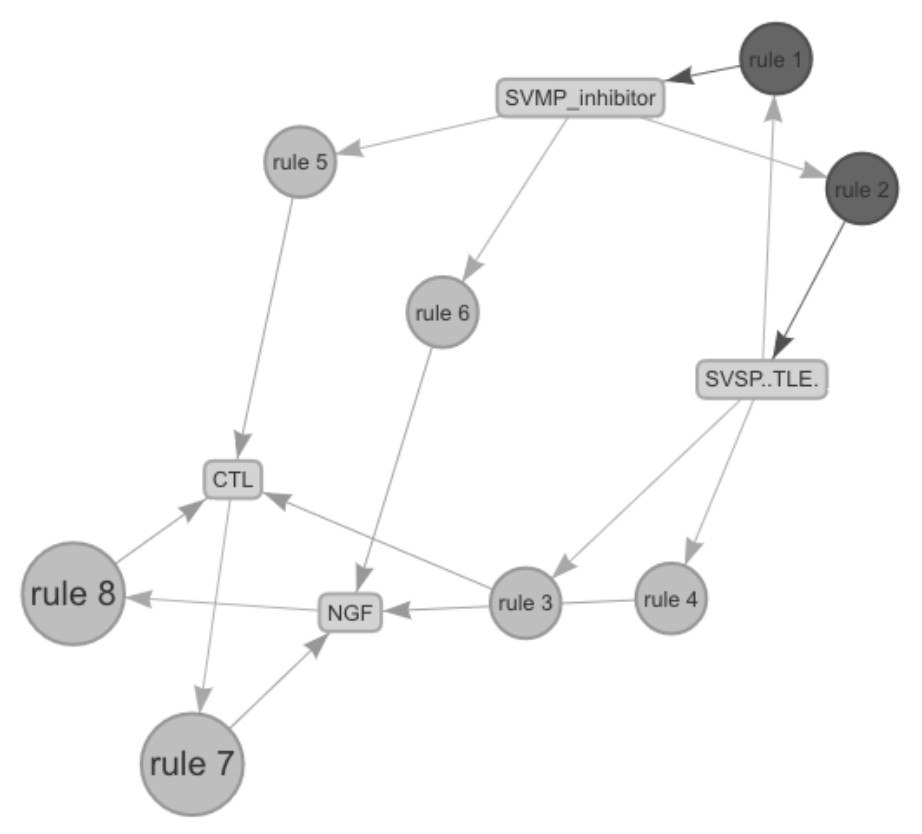

Figure 4. Depictions of association between components of venom expressed by genus Sistrurus. The rules are depicted by top twenty rules as stated in Table 2 .

Table 4. Depictions of association rules between proteins expressed in Sistrurus venom.

\begin{tabular}{llllll}
\hline Rules no. & $\begin{array}{l}\text { Protein } \\
\text { (Predictor) }\end{array}$ & $\begin{array}{l}\text { Protein } \\
\text { (Predicted) }\end{array}$ & Support & Confidence & Lift \\
\hline$[1]$ & SVSP & SVMP inhibitor & 0.5 & 1 & 2 \\
{$[2]$} & SVMP inhibitor & SVSP & 0.5 & 1 & 2 \\
{$[3]$} & SVSP & CTL & 0.5 & 1 & 1.33333333 \\
{$[4]$} & SVSP & NGF & 0.5 & 1 & 1.33333333 \\
{$[5]$} & SVMP inhibitor & CTL & 0.5 & 1 & 1.33333333 \\
{$[6]$} & SVMP inhibitor & NGF & 0.5 & 1 & 1.33333333 \\
{$[7]$} & CTL & NGF & 0.75 & 1 & 1.33333333 \\
{$[8]$} & NGF & CTL & 0.75 & 1 & 1.33333333 \\
\hline
\end{tabular}

Note: C-type Lectins (CTL), Nerve growth factor (NGF), Snake venom metalloprotease (SVMP), Snake venom metalloprotease inhibitor (SVMP inhibitor), Snake venom serine protease (SVSP).

In contrast to Crotalus' venom components, studies on Sistrurus' venom component are lacking and thus, only a small pool of studies were used to generate only 8 associations as depicted in Table 4. Similar to Crotalus' analysis, in this analysis if protein (Predictor) is present in venom, then 
chances of the protein (Predicted) to be expressed in the venom is given by combination of confidence and lift. Both CTL and NGF have the highest amount of associations as a predicted component, which is 3: CTL is associated with NGF, SVMP inhibitor and SVSP; NGF is associated with CTL, SVMP inhibitor and SVSP. Followed by SVMP inhibitor and SVSP with 1 association each: SVMP inhibitor is associated with SVSP and vice versa. However, SVMP inhibitor and SVSP's associations have higher lift and confidence than CTL's and NGF's, indicating better associations.

\section{Discussion}

A total of 46 families of proteins were identified in the venom of 34 species and subspecies of rattlesnakes. The majority of studies have focused on Crotalus, and a subset of studies have focused on Sistrurus. Through our analysis we were able to discover a total of 562 rules for Crotalus and 25 rules for Sistrurus venom components. In this study we present 20 most relevant rules for Crotalus and eight rules for Sistrurus venom components, respectively. There's an emphasis on investigating venom components standalone units with a lack of investigations of their relationships with each other and the subsequent effects of co-administering different components. On the other hand, understanding the relationship between venom components could open a new avenue for biomedical research and unlock protein combinations that yield enhanced bioactivity in pharmaceutical drugs. Additionally, studying components as standalone may have produced a negative effect in which many components have received a skewed attention in biomedical research. For example, protein families are often classified as major or minor based on importance and ubiquity $[13,131]$. Thus, causing the dominant protein families such as Proteases, Neurotoxins, and Phospholipases to enjoy more attention than other protein families such as Growth Factors. However, it is by the combination of ubiquity, bioactivity, and relationship between the protein families that we can classify the venom components as major or minor.

In rattlesnakes MYO, PLA2, SVMP and SVSP are classified as major components based on medical importance and ubiquity $[13,131]$, which is also confirmed by our analysis (Figure 1). However, with a new approach of using both ubiquity and number of associations for each protein, we find that Dis, LAAO, CTL were all more ubiquitous and had more associations with other proteins in Crotalus species (Table 2). Similarly, in Sistrurus species, the SVMP inhibitor and NGF (Figure 4) have most associations as compared to MYO which has only one association (Table 3).

The few studies that have investigated venom proteins based upon their associations have highlighted the synergisms between toxins [76]. This synergism causes the joint effects of multiple toxins to assert greater effects than sum of individual potencies[76], making trace amount of snake venom to be highly efficient and effective [76,77]. Often, such combinations of venom proteins cause a variety of symptoms of bleedings, tissue degradation, necrosis, and further complications in prey and bite victims [72,176] and improve the lethality of whole crude venom in contrast to individual components[76,177].

Through mostly studies of predominant toxins, different general mechanisms for toxin synergisms have been proposed [76,178]:

1) Two or more toxins interacts with different targets on related biological pathways, resulting in synergistically increased toxicity

2) Two or more toxins recognize and interact with the same target in synergistic manner and produce the same effect, and is often called amplification 
3) One toxin (subunit) acts as chaperone to potentiate another one. The chaperone may expose active/functional site of the $2^{\text {nd }}$ toxin (subunit), or expose target sites, or increase affinity to target, or modify active surface of the other toxin (subunit). Such complexes usually dissociate after asserting their toxicity.

Synergisms has mostly been reported in major toxins in rattlesnake venoms[76]. Notable example of synergism through complex formation (mechanism 3) is crotoxin, a lethal neurotoxin from $C$. durissus terrificus, by 2 subunits: an acidic subunit component A (CA or crotapotin) and a basic subunit component B (CB) $[112,118,119,179,180]$. CB is identified as a basic PLA2 with phospholipase activities and low toxicity while the CA component is said to be small acidic, nonenzymatic, nontoxic subunit[76,180]. However, once combine non-covalently, CA improves the potency of $\mathrm{CB}$ by enabling $\mathrm{CB}$ to reach the specific crotoxin receptors at the neuromuscular junction as well as inhibits other CB functions such as catalytic and anticoagulant activities[118,180]. Thus, the resulting crotoxin complex is highly active, comparing to individual components, and showing the synergistic between 2 subunits at blocking acetylcholine release[179,180]. Similarly, in $C$. scutulatus scutulatus, the Mojave toxin is also another PLA2 complex: one acidic and nonlethal subunit acts as a chaperon for the other basic subunit to improves lethality [44,151,165]. Other examples of synergistic complexes have been found and reported in many species of Viperidae and Crotalidae [76]. Such interactions show the strong synergistic activities in rattlesnake venoms that have been studied intensively through previous endeavors.

Although the synergism referenced previously is studied through the scope of complex formation found in snake venoms, other synergisms were studied through co-administration of major toxins[76]. A prevalent example between major components are SVMP P-III and an acidic PLA2 in Bothrops alternatus called Baltergin and Ba SpII RP4 PLA2, respectively[181,182]. In which, Baltergin possess high edematogenic and myotoxic activities [181] while PLA2 has no myotoxicity, although it is the most abundant PLA2 in this specie [182]. When acting simultaneously, both are able to cause complete detachment of $\mathrm{C}_{2} \mathrm{C}_{12}$ myoblast cells, while none can achieve $50 \%$ of detachment on their own[183]. The analogous synergism has also been recorded in endothelial cells, SVMP's natural target[76,184]. The mechanism of synergism for such interaction is said to not based on PLA2 enzymatic activities but is proposed as through interactions with endothelial cells' membranes, free of catalysis[184]. Furthermore, this PLA2 does not target the extracellular matrix proteins like SVMP [181], indicating a mechanism 2 of synergism. Both of these enzymes are present in many rattlesnakes' venoms (Table $1 \& 3$ ) and their association is also reported through our analysis (Table S1) There are reports indicating the synergism between crotoxin and crotamine, a member of MYO toxins in Crotalus venoms, that facilitates the internalization of CB subunit, and increase the neuronal toxicity[76,185]. Unfortunately, these interactions are not found in the analysis (Table 2) although are present in Crotalus venoms (Table 1), which could be due to the sparse reports on Crotalus' venoms with many species are still under-investigated as stated previously.

There are even fewer studies focusing on synergism between major and minor components: SVSP, a major toxin and BPPs, a minor toxin [76], indicating a biased approach in studying venom toxins produced by current major/minor toxin classification convention. BPPs, which are micromolecular hypotensive peptides in snake venoms, can inhibit angiotensin-converting enzyme and induce hypotensive action of bradykinin, accompanied with hyperpermeability of blood 
vessels[68,110,186,187]. Thus, BPPs are targeted for many pharmaceutical developments for treatment of hypertension and heart failure $[188,189]$. On the other hand, many SVSPs show activities that are similar to kallikrein, a serine proteinases, with the specific and limited proteolytic functions that releases bradykinin [76,146,190]. Previous works indicated that BPPs can act synergistically with kallikrein-like SVSPs, which release bradykinin more effectively than endogenous kallikrein and produce potent hypotension and vascular shock in prey[76,98,146,191193] (mechanism 1). Such lack of studies regarding minor components shows the flaw in current classification of major and minor venom components, in which the current SVSP-BPP interaction that produces severe physiological consequences is lacking in number of dedicated researches with many aspects of the interaction remain unclear. Likewise, many components with substantial amount of associations with other toxins, like CTL or NGF, are not investigated at all for their potential synergisms. Therefore, there is a need to develop a deeper understanding of minor components in venom of rattlesnakes to discover more associations such as that of SVSP and BPP.

Another way to explain the associations of these toxins is through the evolution of toxins. One relationship that has been explored in previous studies is between SVMP P-III and Dis. Dis are small, non-enzymatic proteins that can bind to extracellular receptors (integrins) with many motifs and sizes, two of which are RGD and MVD motifs[9,71,147,194,195]. While SVMP-PIII is a subclass of SVMP with a Dis-like domain[196,197]. Dis, especially the RGD/MVD motifs, is suggested to be produced from the rapid evolution occurred in the genes coding of SVMP-PIII[194,195,198]. The RGD/MVD motifs of Dis are presented in many Crotalus species [194] along with the presence of SVMP-PIII, represent as rule 17 (Table 2) can be explained through this evolution model, although the co-association with LAAO is still largely unknown.

Some associations may not need to be derived through their toxicity but could be explained through the proteins' house-keeping functions. The existence of SVMP inhibitor is thought to be a house-keeping molecule, despite its potential therapeutic activities, which helps neutralize the potent SVMP in the venom glands as a self-defense mechanism[199], yet not many studies have been invested in this family along with the lack of appearance in many rattlesnake venoms, where high amount of SVMP exists (Table 1), indicates a gap in knowledge that requires further efforts. Likewise, NGF is known for its ability to inhibit SVMP proteolysis in Viperidae[200,201]. But growing works have suggested other mechanisms in which NGF can act as cytotoxic proapoptotic factors in tissues that don't have TrkA receptors[200,202,203]; or as ancillary functions, like Hya, to help with efficient absorption of venom component through release of granules molecules (histamine, serotonins, etc.) $[178,200,204]$. Such large release can also have its own impactful consequences (anaphylaxis, bronchoconstriction, vasodilation, etc.)[200,205]. However, not many Crotalus species have NGF as seen previously in Table 1, indicating yet another gap of knowledge in Crotalus venomics. Using SVMP as common targeting model to explain the association of NGF and SVMP inhibitor (rule 6, Table 4) is promising, but due to the insufficient amount of information provided, such explanation warrants further attempts in co-administration testing to confirm.

\section{Conclusions}

Through this meta-analysis we have discovered myriad of associations many of which are yet to be described, but they do provide promising potential synergistic effects that are worth investigating. For example, using rules 2 and 13 in Crotalus venoms (Table 2), CTL, a 
protein/glycoprotein that specifically binds to carbohydrate moieties and glycoconjugate, can target and interact with platelet receptors and blood coagulation factors[206], which are also targets for Dis[207], indicate their potential synergisms with antiplatelet toxins and assert the hypotensive results along with many other toxin groups like SVSP[76,98,146,191-193]. Thus, there is a need to characterize toxin components and their associations within the toxicology studies as well as for pharmaceutical interests[72]. With an increase amount of characterization studies, novel families may also be correctly added into the venom profiles such as three-finger toxins (3FTx), which often is present in elapids and a few occasions in rattlesnakes' genome and transcriptome [14-16,168,170]. Furthermore, similar studies for Sistrurus species are still less abundant than their relative Crotalus species, indicating an underdeveloped field of study that warrant further interests. Additionally, this work also address the problem of conventional classification of venom toxins as major or minor based on importance and ubiquity, which are often MYO, PLA2, SVMP and SVSP [13,131], as the cause of much more attention on these dominant toxin families and overlooking other protein families such as Growth Factors. Therefore, we highlight the importance of studying venom components not only as individual components but also in understanding the relationship between them. It is by the combination of ubiquity, bioactivity, and relationship between the protein families that we can classify the venom components as major or minor.

\section{Materials and Methods}

We collected articles and abstracts on venom for each Crotalus and Sistrurus species through the following: databases (PubMed, ScienceDirect, Scopus, Google Scholar, Web of Science), journal's databases (BMC Genomics, Journal of Proteome Research, Journal of Proteomics, Toxicon, Toxicology, Toxins), publisher databases (Wiley Online Library, MDPI, Elsevier). We used "venom" OR "proteomic" OR “venomic" OR “transcriptome" OR "proteome" AND "Name of the species" as keywords for conducting our search. We also, examined references in studies produced from the search results for any additional information. Collected records were earliest obtainable records to those that are published in January of 2020.

From collected records, any article that did not contain information regarding venom composition and components of any Crotalus and Sistrurus species was not used in the current analysis. Otherwise, the articles' full-text version would be further assessed with the following inclusion and exclusion criteria.

For the article to be included in the current analysis, it had to fulfill one of the following criteria: (1) report proteome or transcriptome profile of the venom of any corresponding species; (2) report at least 1 toxin family/component, which is not artificially synthesized based on another similar toxin component; (3) be a comparative study reporting transcriptome/proteome profile for Crotalus, Sistrurus species/subspecies; (4) studies that report variability in venom components for any Crotalus, Sistrurus species/subspecies.

The following criteria were used to exclude any study from the current analysis: (1) reviews that focuses on toxin families and/or articles focuses on the genomic evolution of toxin families; (2) articles with no transcriptome/proteome profiles; (3) articles with no data on toxin family isolated from venom; (4) articles that focuses on new artificially synthesized molecules, based on similar toxin component or recombinant protein/peptides in venom; (5) articles reporting methods to inactivate toxin family from rattlesnakes; (6) case study on rattlesnakes' bites; (7) studies describing methods to 
detect toxin families/components. From the studies that fulfilled our inclusion criteria and did not meet any exclusion criteria we collected and compiled all venom constituents that are reported for each species in the genus Crotalus and Sistrurus in Table 1 and Table 3, respectively. The compiled data was cross-checked by authors for correctness and confirmations.

Using the data from Table 1 and 3 we performed two separate Frequent Item-set data mining analysis for Crotalus and Sistrurus venoms. To conduct Frequent item-set data mining we used only presence absence data. Frequent item-set data mining helps in identifying the association rules associated with the expression of different proteins in venom. Studies on Sistrurus venom components are sparse, thus, can introduce bias towards data-mining analysis. The rules specify the confidence, lift, and support for specific proteins to occur together in venom. Support is defined as absolute frequency, i.e., a support of $25 \%$ means that venom components $\mathrm{x}, \mathrm{y}$, and $\mathrm{z}$ will occur together in $25 \%$ of all venom. Confidence is correlative frequency. i.e., a confidence of $60 \%$ means that if $\mathrm{x}$ and $\mathrm{y}$ occur, then $60 \%$ of times $\mathrm{z}$ will also occur. An association rule is valid only if lift is greater than 1 . Higher the value of the lift, the higher is the validity of the rule. Since, many studies associated with rattlesnake venom concentrated on highly abundant species or species containing more "major components", this affects the performance of the statistical models due to presence of null values. Since, we did only used presence absence data for toxin families from individual studies the chances of bias from individual studies affecting our results were low. With increase in venom composition and variation data, the associations produced by Frequent Item-set data mining analysis will be more informative. All analysis was performed using the software R (R Core Team, 2019).

\section{Supplementary Materials:}

The following is available in the supplementary material attachment. Table S1: Depictions of full association rules between proteins expressed in Crotalus venom.

Author Contributions: Conceptualization, A.D.; methodology, A.D.; validation, A.D. and P.P.; formal analysis, A.D.; investigation, A.D. and P.P.; resources, T.K.S.K and R.K.; data curation, A.D. and P.P.; writing - original draft preparation, A.D. and P.P.; writing - review and editing, P.P., A.D., R.K. and T.K.S.K.; visualization, A.D.; supervision, T.K.S.K; project administration, T.K.S.K and R.K. All authors have read and agreed to the published version of the manuscript.

Funding: This study was supported by grants from the National Institutes of Health (R01 CA172631/CA/NCI \& P30 GM103450/GM/NIGMS) and the Department of Energy (DE-FG0201ER15161).

Acknowledgments: We gratefully acknowledge the support provided by Jyotishka Datta in statistical methods. We are thankful to University of Arkansas, Fayetteville, the Department of Biological Sciences, Department of Biochemistry, and The University of Arkansas, Fort Smith.

Conflicts of Interest: The authors declare no conflict of interest.

\section{Abbreviations}

The following abbreviations are used in this manuscript:

Abbreviation
Full Name

Three-finger toxin 
$5^{\prime}-\mathrm{NT}$

Achase

ANP

ATPase

BIP

BNP

BPP

CTL

CNP

CysProt

CRiSP

CA

CRTX

Dis

EGF

FGF

GC

Hya

Kazal

Kun

LAAO

MTX 5'-nucleotidase

Acetylcholinesterase

Natriuretic peptide type A

Adenosine triphosphatase

Bradykinin inhibitory peptide

Natriuretic peptide type B

Bradykinin potentiate peptide

C-type Lectins

Natriuretic peptide type C

Cysteine Protease

Cysteine-rich secretory protein

crotapotin

Crotoxin

Disintegrin

Epidermal growth factor

Fibroblast growth factor

Guanylyl cyclase

Hyaluronidase

Kazal-type inhibitor

Kunitz-type inhibitor

L-amino acid oxidase

Mojave toxin 


\begin{tabular}{|c|c|}
\hline MYO & Myotoxin \\
\hline NGF & Nerve growth factor \\
\hline OHA & Ohanin \\
\hline PDE & Phosphodiesterase \\
\hline PDGF & Platelet derive growth factor \\
\hline $\mathrm{PLA}_{2}$ & Phospholipase $A_{2}$ \\
\hline PLB & Phospholipase B \\
\hline PLD & Phospholipase D \\
\hline SVMP & Snake venom metalloprotease \\
\hline SVSP & Snake venom serine protease \\
\hline TLE & Thrombin-like enzyme \\
\hline VEGF & $\begin{array}{l}\text { Vascular endothelial growth } \\
\text { factor }\end{array}$ \\
\hline WAP & Waparin \\
\hline
\end{tabular}

\section{References}

1. $\quad$ Fry, B.G.; Wüster, W.; Kini, R.M.; Brusic, V.; Khan, A.; Venkataraman, D.; Rooney, A.P. Molecular evolution and phylogeny of elapid snake venom threefinger toxins. Journal of Molecular Evolution 2003, 57, 110-129, doi:10.1007/s00239-003-2461-2.

2. Adade, C.M.; Carvalho, A.L.O.; Tomaz, M.A.; Costa, T.F.R.; Godinho, J.L.; Melo, P.A.; Lima, A.P.C.A.; Rodrigues, J.C.F.; Zingali, R.B.; Souto-Padrón, T. Crovirin, a snake venom cysteine-rich secretory protein (CRISP) with promising activity against Trypanosomes and Leishmania. PLoS neglected tropical diseases 2014, 8, e3252, doi:10.1371/journal.pntd.0003252.

3. Sanchez, E.E.; Galan, J.A.; Russell, W.K.; Soto, J.G.; Russell, D.H.; Perez, J.C. Isolation and characterization of two disintegrins inhibiting ADP-induced human platelet aggregation from the venom of Crotalus scutulatus scutulatus (Mohave Rattlesnake). Toxicol Appl Pharmacol 2006, 212, 59-68, doi:10.1016/j.taap.2005.07.004. 
4. Suntravat, M.; Jia, Y.; Lucena, S.E.; Sánchez, E.E.; Pérez, J.C. cDNA cloning of a snake venom metalloproteinase from the eastern diamondback rattlesnake (Crotalus adamanteus), and the expression of its disintegrin domain with anti-platelet effects. Toxicon: Official Journal of the International Society on Toxinology 2013, 64, 4354, doi:10.1016/j.toxicon.2012.12.025.

5. Suntravat, M.; Barret, H.S.; Jurica, C.A.; Lucena, S.E.; Perez, J.C.; Sánchez, E.E. Recombinant disintegrin (r-Cam-dis) from Crotalus adamanteus inhibits adhesion of human pancreatic cancer cell lines to laminin-1 and vitronectin. Journal of Venom Research 2015, 6, 1-10.

6. Galán, J.A.; Sánchez, E.E.; Rodríguez-Acosta, A.; Soto, J.G.; Bashir, S.; McLane, M.A.; Paquette-Straub, C.; Pérez, J.C. Inhibition of lung tumor colonization and cell migration with the disintegrin crotatroxin 2 isolated from the venom of Crotalus atrox. Toxicon: Official Journal of the International Society on Toxinology 2008, 51, 1186-1196, doi:10.1016/j.toxicon.2008.02.004.

7. Mackessy, S.; Saviola, A.; Mukherjee, A. Venom toxins to drugs: Anti-thrombotic and anti-metastasis compounds from snake venoms. Toxicon 2018, 150, 320, doi:10.1016/j.toxicon.2018.06.016.

8. Arruda Macedo, J.K.; Fox, J.W.; de Souza Castro, M. Disintegrins from snake venoms and their applications in cancer research and therapy. Curr Protein Pept Sci 2015, 16, 532-548.

9. Da Silva, M.; Lucena, S.; Aguilar, I.; Rodriguez-Acosta, A.; Salazar, A.M.; Sanchez, E.E.; Giron, M.E.; Carvajal, Z.; Arocha-Pinango, C.L.; Guerrero, B. Antiplatelet effect of cumanastatin 1, a disintegrin isolated from venom of South American Crotalus rattlesnake. Thromb Res 2009, 123, 731-739, doi:10.1016/j.thromres.2008.08.001.

10. Fox, J.W.; Serrano, S.M. Approaching the golden age of natural product pharmaceuticals from venom libraries: an overview of toxins and toxin-derivatives currently involved in therapeutic or diagnostic applications. Curr Pharm Des 2007, 13, 2927-2934, doi:10.2174/138161207782023739.

11. Lucena, S.E.; Romo, K.; Suntravat, M.; Sánchez, E.E. Anti-angiogenic activities of two recombinant disintegrins derived from the Mohave and Prairie rattlesnakes. Toxicon 2014, 78, 10-17, doi:10.1016/j.toxicon.2013.11.005.

12. Urra, F.A.; Araya-Maturana, R. Targeting Metastasis with Snake Toxins: Molecular Mechanisms. Toxins 2017, 9, 390, doi:10.3390/toxins9120390.

13. Tasoulis, T.; Isbister, G.K. A Review and Database of Snake Venom Proteomes. Toxins 2017, 9, doi:10.3390/toxins9090290.

14. Kumar, T.; Yang, P.; Lin, S.; Wu, C.; Lei, B.; Lo, S.; Tu, S.-C.; Yu, C. Cloning, Direct Expression, and Purification of a Snake Venom Cardiotoxin inEscherichia coli. Biochemical and biophysical research communications 1996, 219, 450-456.

15. Kumar, T.; Jayaraman, G.; Lee, C.S.; Arunkumar, A.; Sivaraman, T.; Samuel, D.; $\mathrm{Yu}, \mathrm{C}$. Snake venom cardiotoxins-structure, dynamics, function and folding. Journal of Biomolecular Structure and Dynamics 1997, 15, 431-463. 
16. Sivaraman, T.; Kumar, T.; Tu, Y.; Peng, H.; Yu, C. Structurally homologous toxins isolated from the Taiwan cobra (Naja naja atra) differ significantly in their structural stability. Archives of biochemistry and biophysics 1999, 363, 107-115.

17. Daltry, J.C.; Wuster, W.; Thorpe, R.S. Diet and snake venom evolution. Nature 1996, 379, 537-540, doi:10.1038/379537a0.

18. Fry, B.G.; Wickramaratna, J.C.; Hodgson, W.C.; Alewood, P.F.; Kini, R.; Ho, H.; Wüster, W. Electrospray liquid chromatography/mass spectrometry fingerprinting of Acanthophis (death adder) venoms: taxonomic and toxinological implications. Rapid communications in mass spectrometry 2002, 16, 600-608.

19. Assakura, M.T.; Salomao, M.G.; Puorto, G.; Mandelbaum, F.R. Hemorrhagic, fibrinogenolytic and edema-forming activities of the venom of the colubrid snake Philodryas olfersii (green snake). Toxicon 1992, 30, 427-438, doi:10.1016/00410101(92)90539-h.

20. Jimenez Porras, J.M. INTRASPECIFIC VARIATIONS IN COMPOSITION OF VENOM OF THE JUMPING VIPER, BOTHROPS NUMMIFERA. Toxicon 1964, 2, 187-195, doi:10.1016/0041-0101(64)90021-2.

21. Glenn, J.L.; Straight, R.C.; Wolfe, M.C.; Hardy, D.L. Geographical variation in Crotalus scutulatus scutulatus (Mojave rattlesnake) venom properties. Toxicon 1983, 21, 119-130, doi:10.1016/0041-0101(83)90055-7.

22. Yang, C.C.; Chang, L.S.; Wu, F.S. Venom constituents of Notechis scutatus scutatus (Australian tiger snake) from differing geographic regions. Toxicon 1991, 29, 1337-1344, doi:10.1016/0041-0101(91)90120-g.

23. Barlow, A.; Pook, C.E.; Harrison, R.A.; Wuster, W. Coevolution of diet and preyspecific venom activity supports the role of selection in snake venom evolution. Proc Biol Sci 2009, 276, 2443-2449, doi:10.1098/rspb.2009.0048.

24. Saravia, N.G.; Weigle, K.; Navas, C.; Segura, I.; Valderrama, L.; Valencia, A.Z.; Escorcia, B.; McMahon-Pratt, D. Heterogeneity, geographic distribution, and pathogenicity of serodemes of Leishmania viannia in Colombia. Am J Trop Med Hyg 2002, 66, 738-744, doi:10.4269/ajtmh.2002.66.738.

25. Creer, S.; Malhotra, A.; Thorpe, R.S.; Stocklin, R.S.; Favreau, P.S.; Hao Chou, W.S. Genetic and ecological correlates of intraspecific variation in pitviper venom composition detected using matrix-assisted laser desorption time-of-flight mass spectrometry (MALDI-TOF-MS) and isoelectric focusing. J Mol Evol 2003, 56, 317-329, doi:10.1007/s00239-002-2403-4.

26. Tonello, F.; Simonato, M.; Aita, A.; Pizzo, P.; Fernandez, J.; Lomonte, B.; Gutierrez, J.M.; Montecucco, C. A Lys49-PLA2 myotoxin of Bothrops asper triggers a rapid death of macrophages that involves autocrine purinergic receptor signaling. Cell Death Dis 2012, 3, e343, doi:10.1038/cddis.2012.68.

27. Fry, B. Venomous reptiles and their toxins: evolution, pathophysiology and biodiscovery; Oxford University Press: 2015.

28. Mackessy, S.P.; Sixberry, N.M.; Heyborne, W.H.; Fritts, T. Venom of the Brown Treesnake, Boiga irregularis: ontogenetic shifts and taxa-specific toxicity. Toxicon: 
Official Journal of the International Society on Toxinology 2006, 47, 537-548, doi:10.1016/j.toxicon.2006.01.007.

29. Rokyta, D.R.; Margres, M.J.; Calvin, K. Post-transcriptional Mechanisms Contribute Little to Phenotypic Variation in Snake Venoms. G3: Genes, Genomes, Genetics 2015, 5, 2375-2382, doi:10.1534/g3.115.020578.

30. Calvete, J.J.; Juarez, P.; Sanz, L. Snake venomics. Strategy and applications. J Mass Spectrom 2007, 42, 1405-1414, doi:10.1002/jms.1242.

31. Cintra, A.C.O.; De Toni, L.G.B.; Sartim, M.A.; Franco, J.J.; Caetano, R.C.; Murakami, M.T.; Sampaio, S.V. Batroxase, a new metalloproteinase from B. atrox snake venom with strong fibrinolytic activity. Toxicon 2012, 60, 70-82, doi:10.1016/j.toxicon.2012.03.018.

32. Fox, J.W. A brief review of the scientific history of several lesser-known snake venom proteins: 1-amino acid oxidases, hyaluronidases and phosphodiesterases. Toxicon 2013, 62, 75-82, doi:10.1016/j.toxicon.2012.09.009.

33. Kordis, D.; Gubensek, F. Adaptive evolution of animal toxin multigene families. Gene 2000, 261, 43-52, doi:10.1016/s0378-1119(00)00490-x.

34. Moura-da-Silva, A.M.; Paine, M.J.I.; Diniz, M.R.V.; Theakston, R.D.G.; Crampton, J.M. The molecular cloning of a phospholipase A 2 from Bothrops jararacussu snake venom: Evolution of venom group II phospholipase A 2 's may imply gene duplications. Journal of Molecular Evolution 2020, 41, 174-179, doi:doi:10.1007/BF00170670.

35. Slowinski, J.B.; Knight, A.; Rooney, A.P. Inferring species trees from gene trees: a phylogenetic analysis of the Elapidae (Serpentes) based on the amino acid sequences of venom proteins. Mol Phylogenet Evol 1997, 8, 349-362, doi:10.1006/mpev.1997.0434.

36. Afifiyan, F.; Armugam, A.; Tan, C.H.; Gopalakrishnakone, P.; Jeyaseelan, K. Postsynaptic $\alpha$-Neurotoxin Gene of the Spitting Cobra, Naja naja sputatrix: Structure, Organization, and Phylogenetic Analysis. Genome Res 1999, 9, 259-266.

37. Chang, L.; Lin, S.; Huang, H.; Hsiao, M. Genetic organization of alphabungarotoxins from Bungarus multicinctus (Taiwan banded krait): evidence showing that the production of alpha-bungarotoxin isotoxins is not derived from edited mRNAs. Nucleic Acids Res 1999, 27, 3970-3975, doi:10.1093/nar/27.20.3970.

38. Poran, N.S.; Coss, R.G.; Benjamini, E. Resistance of California ground squirrels (Spermophilus beecheyi) to the venom of the northern Pacific rattlesnake (Crotalus viridis oreganus): a study of adaptive variation. Toxicon 1987, 25, 767-777, doi:10.1016/0041-0101(87)90127-9.

39. WuÈster, W.; Daltry, J.C.; Thorpe, R.S. Can diet explain intraspecific venom variation? Reply to Sasa. TOXICON-OXFORD- 1999, 37, 253-258.

40. Heatwole, H.; Poran, N.S. Resistances of sympatric and allopatric eels to sea snake venoms. Copeia 1995, 136-147. 
41. Kocholaty, W.F.; Ledford, E.B.; Daly, J.G.; Billings, T.A. Toxicity and some enzymatic properties and activities in the venoms of Crotalidae, Elapidae and Viperidae. Toxicon 1971, 9, 131-138, doi:10.1016/0041-0101(71)90006-7.

42. Campbell, J.A.; Lamar, W.W.; Brodie, E.D. The venomous reptiles of the Western Hemisphere; Comstock Pub. Associates Ithaca [NY]: 2004; Vol. 2.

43. Arnaud-Franco, G.; Cordero-Tapia, A.; Ortiz-Avila, V.; Moctezuma-Gonzalez, C.L.; Tejocote-Perez, M.; Carbajal-Saucedo, A. Comparison of biological and biochemical characteristics of venom from rattlesnakes in the southern Baja California Peninsula. Toxicon 2018, 148, 197-201, doi:10.1016/j.toxicon.2018.04.030.

44. Borja, M.; Neri-Castro, E.; Castaneda-Gaytan, G.; Strickland, J.L.; Parkinson, C.L.; Castaneda-Gaytan, J.; Ponce-Lopez, R.; Lomonte, B.; Olvera-Rodriguez, A.; Alagon, A., et al. Biological and Proteolytic Variation in the Venom of Crotalus scutulatus scutulatus from Mexico. Toxins (Basel) 2018, 10, doi:10.3390/toxins10010035.

45. Mackessy, S.P. Evolutionary trends in venom composition in the western rattlesnakes (Crotalus viridis sensu lato): toxicity vs. tenderizers. Toxicon 2010, 55, 1463-1474, doi:10.1016/j.toxicon.2010.02.028.

46. Findrik, Z.; Vasić-Rački, Đ.; Primožič, M.; Habulin, M.; Knez, Ž. Enzymatic activity of L-amino acid oxidase from snake venom Crotalus adamanteus in supercritical CO2. Biocatalysis and Biotransformation 2005, 23, 315-321, doi:10.1080/10242420500285694.

47. Calvete, J.J.; Fasoli, E.; Sanz, L.; Boschetti, E.; Righetti, P.G. Exploring the venom proteome of the western diamondback rattlesnake, Crotalus atrox, via snake venomics and combinatorial peptide ligand library approaches. Journal of Proteome Research 2009, 8, 3055-3067, doi:10.1021/pr900249q.

48. Boldrini-Franca, J.; Correa-Netto, C.; Silva, M.M.; Rodrigues, R.S.; De La Torre, P.; Perez, A.; Soares, A.M.; Zingali, R.B.; Nogueira, R.A.; Rodrigues, V.M., et al. Snake venomics and antivenomics of Crotalus durissus subspecies from Brazil: assessment of geographic variation and its implication on snakebite management. $J$ Proteomics 2010, 73, 1758-1776, doi:10.1016/j.jprot.2010.06.001.

49. Costa, T.R.; Burin, S.M.; Menaldo, D.L.; de Castro, F.A.; Sampaio, S.V. Snake venom L-amino acid oxidases: an overview on their antitumor effects. The Journal of Venomous Animals and Toxins Including Tropical Diseases 2014, 20, 23, doi:10.1186/1678-9199-20-23.

50. Mackessy, S.P. Fractionation of red diamond rattlesnake (Crotalus ruber ruber) venom: protease, phosphodiesterase, L-amino acid oxidase activities and effects of metal ions and inhibitors on protease activity. Toxicon 1985, 23, 337-340, doi:10.1016/0041-0101(85)90157-6.

51. Mackessy, S.P.; Leroy, J.; Mociño-Deloya, E.; Setser, K.; Bryson, R.W.; Saviola, A.J. Venom Ontogeny in the Mexican Lance-Headed Rattlesnake (Crotalus polystictus). Toxins 2018, 10, doi:10.3390/toxins10070271. 
52. Saviola, A.J.; Gandara, A.J.; Bryson, R.W., Jr.; Mackessy, S.P. Venom phenotypes of the Rock Rattlesnake (Crotalus lepidus) and the Ridge-nosed Rattlesnake (Crotalus willardi) from Mexico and the United States. Toxicon 2017, 138, 119-129, doi:10.1016/j.toxicon.2017.08.016.

53. Komori, Y.; Sakai, K.; Masuda, K.; Nikai a, T. Isolation and Biochemical Characterization of Rubelase, a Non-Hemorrhagic Elastase from Crotalus ruber ruber (Red Rattlesnake) Venom. Toxins (Basel) 2011, 3, 900-910, doi:10.3390/toxins3070900.

54. Mackessy, S.P. Characterization of the major metalloprotease isolated from the venom of the northern pacific rattlesnake, Crotalus viridis oreganus. Toxicon 1996, 34, 1277-1285, doi:10.1016/s0041-0101(96)00100-6.

55. Smith, C.F.; Mackessy, S.P. The effects of hybridization on divergent venom phenotypes: Characterization of venom from Crotalus scutulatus scutulatus $\mathrm{x}$ Crotalus oreganus helleri hybrids. Toxicon 2016, 120, 110-123, doi:10.1016/j.toxicon.2016.08.001.

56. Boldrini-Franca, J.; Pinheiro-Junior, E.L.; Arantes, E.C. Functional and biological insights of rCollinein-1, a recombinant serine protease from Crotalus durissus collilineatus. J Venom Anim Toxins Incl Trop Dis 2019, 25, e147118, doi:10.1590/1678-9199-jvatitd-1471-18.

57. Calvete, J.J.; Sanz, L.; Cid, P.; de la Torre, P.; Flores-Diaz, M.; Dos Santos, M.C.; Borges, A.; Bremo, A.; Angulo, Y.; Lomonte, B., et al. Snake venomics of the Central American rattlesnake Crotalus simus and the South American Crotalus durissus complex points to neurotoxicity as an adaptive paedomorphic trend along Crotalus dispersal in South America. J Proteome Res 2010, 9, 528-544, doi:10.1021/pr9008749.

58. Calvete, J.J.; Perez, A.; Lomonte, B.; Sanchez, E.E.; Sanz, L. Snake venomics of Crotalus tigris: the minimalist toxin arsenal of the deadliest Nearctic rattlesnake venom. Evolutionary Clues for generating a pan-specific antivenom against crotalid type II venoms [corrected]. J Proteome Res 2012, 11, 1382-1390, doi:10.1021/pr201021d.

59. Almeida, J.R.; Resende, L.M.; Silva, A.G.; Ribeiro, R.I.; Stabeli, R.G.; Soares, A.M.; Calderon, L.A.; Marangoni, S.; Da Silva, S.L. Biochemical and functional studies of ColTx-I, a new myotoxic phospholipase A2 isolated from Crotalus oreganus lutosus (Great Basin rattlesnake) snake venom. Toxicon 2016, 117, 1-12, doi:10.1016/j.toxicon.2016.03.008.

60. Almeida, J.R.; Lancellotti, M.; Soares, A.M.; Calderon, L.A.; Ramirez, D.; Gonzalez, W.; Marangoni, S.; Da Silva, S.L. CoaTx-II, a new dimeric Lys49 phospholipase A2 from Crotalus oreganus abyssus snake venom with bactericidal potential: Insights into its structure and biological roles. Toxicon 2016, 120, 147158, doi:10.1016/j.toxicon.2016.08.007.

61. Macías-Rodríguez, E.F.; Díaz-Cárdenas, C.O.; Gatica-Colima, A.B.; PlengeTellechea, L.F. Seasonal variation in protein content and PLA2 activity of Crotalus 
molossus_molossus venom from captive and wild specimens. Acta Universitaria 2014, 24, 38-47, doi:10.15174/au.2014.430.

62. Rivas, E.; Neri, E.; Benard, M.; I. Hernánez-Dávila, A.; Zamudio, F.; Alagón, A. General characterization of the venoms from two species of rattlesnakes and an intergrade population ( C. lepidus x aquilus ) from Aguascalientes and Zacatecas, Mexico. Toxicon 2017, 138, doi:10.1016/j.toxicon.2017.09.002.

63. Griffin, P.R.; Aird, S.D. A new small myotoxin from the venom of the prairie rattlesnake (Crotalus viridis viridis). FEBS Lett 1990, 274, 43-47, doi:10.1016/0014-5793(90)81325-i.

64. Ownby, C.L.; Colberg, T.R.; White, S.P. Isolation, characterization and crystallization of a phospholipase A2 myotoxin from the venom of the prairie rattlesnake (Crotalus viridis viridis). Toxicon 1997, 35, 111-124, doi:10.1016/s0041-0101(96)00054-2.

65. Saviola, A.J.; Pla, D.; Sanz, L.; Castoe, T.A.; Calvete, J.J.; Mackessy, S.P. Comparative venomics of the Prairie Rattlesnake (Crotalus viridis viridis) from Colorado: Identification of a novel pattern of ontogenetic changes in venom composition and assessment of the immunoreactivity of the commercial antivenom CroFab(R). J Proteomics 2015, 121, 28-43, doi:10.1016/j.jprot.2015.03.015.

66. Strickland, J.L.; Mason, A.J.; Rokyta, D.R.; Parkinson, C.L. Phenotypic Variation in Mojave Rattlesnake (Crotalus scutulatus) Venom Is Driven by Four Toxin Families. Toxins (Basel) 2018, 10, doi:10.3390/toxins10040135.

67. Evangelista, J.S.A.M.; Martins, A.M.C.; Nascimento, N.R.F.; Sousa, C.M.; Alves, R.S.; Toyama, D.O.; Toyama, M.H.; Evangelista, J.J.F.; Menezes, D.B.d.; Fonteles, M.C., et al. Renal and vascular effects of the natriuretic peptide isolated from Crotalus durissus cascavella venom. Toxicon: Official Journal of the International Society on Toxinology 2008, 52, 737-744, doi:10.1016/j.toxicon.2008.08.014.

68. Gomes, C.L.; Konno, K.; Conceição, I.M.; Ianzer, D.; Yamanouye, N.; Prezoto, B.C.; Assakura, M.T.; Rádis-Baptista, G.; Yamane, T.; Santos, R.A., et al. Identification of novel bradykinin-potentiating peptides (BPPs) in the venom gland of a rattlesnake allowed the evaluation of the structure-function relationship of BPPs. Biochemical Pharmacology 2007, 74, 1350-1360, doi:10.1016/j.bcp.2007.07.014.

69. Carey, C.M.; Bueno, R.; Gutierrez, D.A.; Petro, C.; Lucena, S.E.; Sanchez, E.E.; Soto, J.G. Recombinant rubistatin (r-Rub), an MVD disintegrin, inhibits cell migration and proliferation, and is a strong apoptotic inducer of the human melanoma cell line SK-Mel-28. Toxicon 2012, 59, 241-248, doi:10.1016/j.toxicon.2011.12.002.

70. Saviola, A.J.; Modahl, C.M.; Mackessy, S.P. Disintegrins of Crotalus simus tzabcan venom: Isolation, characterization and evaluation of the cytotoxic and anti-adhesion activities of tzabcanin, a new RGD disintegrin. Biochimie 2015, 116, 92-102, doi:10.1016/j.biochi.2015.07.005. 
71. Saviola, A.J.; Burns, P.D.; Mukherjee, A.K.; Mackessy, S.P. The disintegrin tzabcanin inhibits adhesion and migration in melanoma and lung cancer cells. Int $J$ Biol Macromol 2016, 88, 457-464, doi:10.1016/j.ijbiomac.2016.04.008.

72. Roldán-Padrón, O.; Castro-Guillén, J.L.; García-Arredondo, J.A.; Cruz-Pérez, M.S.; Díaz-Peña, L.F.; Saldaña, C.; Blanco-Labra, A.; García-Gasca, T. Snake Venom Hemotoxic Enzymes: Biochemical Comparison between Crotalus Species from Central Mexico. Molecules (Basel, Switzerland) 2019, 24, doi:10.3390/molecules24081489.

73. Gibbs, H.L.; Mackessy, S.P. Functional basis of a molecular adaptation: preyspecific toxic effects of venom from Sistrurus rattlesnakes. Toxicon 2009, 53, 672679, doi:10.1016/j.toxicon.2009.01.034.

74. Gibbs, H.L.; Sanz, L.; Sovic, M.G.; Calvete, J.J. PMC3691181; Phylogeny-based comparative analysis of venom proteome variation in a clade of rattlesnakes (Sistrurus sp.). PLoS One 2013, 8, e67220, doi:10.1371/journal.pone.0067220. Print 2013.; ID: 192

10.1371/journal.pone.0067220.

75. Casewell, N.R.; Wagstaff, S.C.; Wüster, W.; Cook, D.A.; Bolton, F.M.; King, S.I.; Pla, D.; Sanz, L.; Calvete, J.J.; Harrison, R.A. Medically important differences in snake venom composition are dictated by distinct postgenomic mechanisms. Proceedings of the National Academy of Sciences 2014, 111, 9205-9210.

76. S, X.; C, H. Synergistic Strategies of Predominant Toxins in Snake Venoms. Toxicology letters 2018, 287, doi:10.1016/j.toxlet.2018.02.004.

77. JP, G.; VJ, F.; J, S. Toxicology of Simple and Complex Mixtures. Trends in pharmacological sciences 2001, 22, doi:10.1016/s0165-6147(00)01720-x.

78. Buschek, S.; Ignjatovic, V.; Summerhayes, R.; Lowe, R. The effect of different snake venoms and anti-venoms on thrombin clotting time in human plasma. Thromb Res 2010, 125, e149-152, doi:10.1016/j.thromres.2009.10.020.

79. Castro, E.N.; Lomonte, B.; del Carmen Gutierrez, M.; Alagon, A.; Gutierrez, J.M. Intraspecies variation in the venom of the rattlesnake Crotalus simus from Mexico: different expression of crotoxin results in highly variable toxicity in the venoms of three subspecies. J Proteomics 2013, 87, 103-121, doi:10.1016/j.jprot.2013.05.024.

80. Viala, V.L.; Hildebrand, D.; Fucase, T.M.; Sciani, J.M.; Prezotto-Neto, J.P.; Riedner, M.; Sanches, L.; Nishimura, P.J.; Oguiura, N.; Pimenta, D.C., et al. Proteomic analysis of the rare Uracoan rattlesnake Crotalus vegrandis venom: Evidence of a broad arsenal of toxins. Toxicon 2015, 107, 234-251, doi:10.1016/j.toxicon.2015.09.023.

81. Margres, M.J.; McGivern, J.J.; Wray, K.P.; Seavy, M.; Calvin, K.; Rokyta, D.R. Linking the transcriptome and proteome to characterize the venom of the eastern diamondback rattlesnake (Crotalus adamanteus). Journal of Proteomics 2014, 96, 145-158, doi:10.1016/j.jprot.2013.11.001.

82. Rokyta, D.R.; Lemmon, A.R.; Margres, M.J.; Aronow, K. The venom-gland transcriptome of the eastern diamondback rattlesnake (Crotalus adamanteus). BMC genomics 2012, 13, 312, doi:10.1186/1471-2164-13-312. 
83. Rokyta, D.R.; Wray, K.P.; Lemmon, A.R.; Lemmon, E.M.; Caudle, S.B. A highthroughput venom-gland transcriptome for the Eastern Diamondback Rattlesnake (Crotalus adamanteus) and evidence for pervasive positive selection across toxin classes. Toxicon: Official Journal of the International Society on Toxinology 2011, 57, 657-671, doi:10.1016/j.toxicon.2011.01.008.

84. Vincent, M.; Curti, B. On the Reaction Mechanism of Crotalus adamanteus 1-Amino Acid Oxidase. Journal of Biological Chemistry 1967, 242, 1259-1264.

85. Heinrikson, R.L.; Krueger, E.T.; Keim, P.S. Amino acid sequence of phospholipase A2-alpha from the venom of Crotalus adamanteus. A new classification of phospholipases A2 based upon structural determinants. J Biol Chem 1977, 252, 4913-4921.

86. Jia, Y.; Olvera, P.; Rangel, F.; Mendez, B.; Reddy, S. Rapid Identification of Phospholipase A2 Transcripts from Snake Venoms. In Toxins (Basel), 2019; Vol. 11.

87. Wellner, D.; Meister, A. Crystalline L-amino acid oxidase of Crotalus adamanteus. The Journal of Biological Chemistry 1960, 235, 2013-2018.

88. Samy, R.P.; Kandasamy, M.; Gopalakrishnakone, P.; Stiles, B.G.; Rowan, E.G.; Becker, D.; Shanmugam, M.K.; Sethi, G.; Chow, V.T.K. Wound healing activity and mechanisms of action of an antibacterial protein from the venom of the eastern diamondback rattlesnake (Crotalus adamanteus). PloS One 2014, 9, e80199, doi:10.1371/journal.pone.0080199.

89. Rokyta, D.R.; Margres, M.J.; Ward, M.J.; Sanchez, E.E. The genetics of venom ontogeny in the eastern diamondback rattlesnake (Crotalus adamanteus). PeerJ 2017, 5, e3249, doi:10.7717/peerj.3249.

90. Gomis-Rüth, F.X.; Kress, L.F.; Kellermann, J.; Mayr, I.; Lee, X.; Huber, R.; Bode, W. Refined 2.0 ^ X-ray Crystal Structure of the Snake Venom Zinc-endopeptidase Adamalysin II: Primary and Tertiary Structure Determination, Refinement, Molecular Structure and Comparison with Astacin, Collagenase and Thermolysin. Journal of Molecular Biology 1994, 239, 513-544, doi:10.1006/jmbi.1994.1392.

91. Suntravat, M.; Langlais, P.R.; Sánchez, E.E.; Nielsen, V.G. CatroxMP-II: a hememodulated fibrinogenolytic metalloproteinase isolated from Crotalus atrox venom. Biometals: An International Journal on the Role of Metal Ions in Biology, Biochemistry, and Medicine 2018, 31, 585-593, doi:10.1007/s10534-018-0107-5.

92. Sultan, M.T.; Li, H.-M.; Lee, Y.Z.; Lim, S.S.; Song, D.-K. Identification of Lys49PLA2 from crude venom of Crotalus atrox as a human neutrophil-calcium modulating protein. The Korean Journal of Physiology \& Pharmacology 2016, 20, 177-183, doi:10.4196/kjpp.2016.20.2.177.

93. Igarashi, T.; Araki, S.; Mori, H.; Takeda, S. Crystal structures of catrocollastatin/VAP2B reveal a dynamic, modular architecture of ADAM/adamalysin/reprolysin family proteins. FEBS letters 2007, 581, 2416-2422, doi:10.1016/j.febslet.2007.04.057. 
94. Fox, J.W.; Serrano, S.M.T. Timeline of key events in snake venom metalloproteinase research. Journal of Proteomics 2009, 72, 200-209, doi:10.1016/j.jprot.2009.01.015.

95. Torii, S.; Naito, M.; Tsuruo, T. Apoxin I, a novel apoptosis-inducing factor with Lamino acid oxidase activity purified from Western diamondback rattlesnake venom. The Journal of Biological Chemistry 1997, 272, 9539-9542, doi:10.1074/jbc.272.14.9539.

96. Kikushima, E.; Nakamura, S.; Oshima, Y.; Shibuya, T.; Miao, J.Y.; Hayashi, H.; Nikai, T.; Araki, S. Hemorrhagic activity of the vascular apoptosis-inducing proteins VAP1 and VAP2 from Crotalus atrox. Toxicon: Official Journal of the International Society on Toxinology 2008, 52, 589-593, doi:10.1016/j.toxicon.2008.06.027.

97. Bjarnason, J.B.; Fox, J.W. Proteolytic specificity and cobalt exchange of hemorrhagic toxin e, a zinc protease isolated from the venom of the western diamondback rattlesnake (Crotalus atrox). Biochemistry 1983, 22, 3770-3778, doi:10.1021/bi00285a009.

98. JB, B.; A, B.; GS, D.; R, C.; JW, F. Kallikrein-like Enzymes From Crotalus Atrox Venom. The Journal of biological chemistry 1983, 258.

99. Segura, A.; Herrera, M.; Mares, F.R.; Jaime, C.; Sanchez, A.; Vargas, M.; Villalta, M.; Gomez, A.; Gutierrez, J.M.; Leon, G. Proteomic, toxicological and immunogenic characterization of Mexican west -coast rattlesnake (Crotalus basiliscus) venom and its immunological relatedness with the venom of Central American rattlesnake (Crotalus simus). JOURNAL OF PROTEOMICS 2017, 158, 62-72, doi:10.1016/j.jprot.2017.02.015.

100. Datta, G.; Dong, A.; Witt, J.; Tu, A.T. Biochemical characterization of basilase, a fibrinolytic enzyme from Crotalus basiliscus basiliscus. Arch Biochem Biophys 1995, 317, 365-373, doi:10.1006/abbi.1995.1176.

101. RM, S.; JW, R.; MA, N.; DR, P.; L, N.; A, A.; AM, C.; IF, C. Characterization of the Integrin Specificities of Disintegrins Isolated From American Pit Viper Venoms. The Journal of biological chemistry 1993, 268.

102. Retzios, A.D.; Markland, J.F.S. Purification, characterization, and fibrinogen cleavage sites of three fibrinolytic enzymes from the venom of Crotalus basiliscus basiliscus. Biochemistry 1992, 31, 4547-4557, doi:10.1021/bi00134a003.

103. Rautsaw, R.M.; Hofmann, E.P.; Margres, M.J.; Holding, M.L.; Strickland, J.L.; Mason, A.J.; Rokyta, D.R.; Parkinson, C.L. Intraspecific sequence and gene expression variation contribute little to venom diversity in sidewinder rattlesnakes ( Crotalus cerastes). Proc Biol Sci 2019, 286, 20190810, doi:10.1098/rspb.2019.0810.

104. Hofmann, E.P.; Rautsaw, R.M.; Strickland, J.L.; Holding, M.L.; Hogan, M.P.; Mason, A.J.; Rokyta, D.R.; Parkinson, C.L. Comparative venom-gland transcriptomics and venom proteomics of four Sidewinder Rattlesnake (Crotalus cerastes) lineages reveal little differential expression despite individual variation. Sci Rep 2018, 8, 15534, doi:10.1038/s41598-018-33943-5. 
105. Bosak, A.R.; Ruha, A.M.; Graeme, K.A. A case of neurotoxicity following envenomation by the Sidewinder rattlesnake, Crotalus cerastes. J Med Toxicol 2014, 10, 229-231, doi:10.1007/s13181-013-0373-0.

106. Bandeira, I.C.J.; Bandeira-Lima, D.; Mello, C.P.; Pereira, T.P.; De Menezes, R.; Sampaio, T.L.; Falcao, C.B.; Radis-Baptista, G.; Martins, A.M.C. Antichagasic effect of crotalicidin, a cathelicidin-like vipericidin, found in Crotalus durissus terrificus rattlesnake's venom gland. Parasitology 2018, 145, 1059-1064, doi:10.1017/s0031182017001846.

107. Wiezel, G.A.; Shibao, P.Y.T.; Cologna, C.T.; Morandi Filho, R.; Ueira-Vieira, C.; De Pauw, E.; Quinton, L.; Arantes, E.C. In-Depth Venome of the Brazilian Rattlesnake Crotalus durissus terrificus: An Integrative Approach Combining Its Venom Gland Transcriptome and Venom Proteome. J Proteome Res 2018, 17, 3941-3958, doi:10.1021/acs.jproteome.8b00610.

108. Bordon, K.C.; Perino, M.G.; Giglio, J.R.; Arantes, E.C. Isolation, enzymatic characterization and antiedematogenic activity of the first reported rattlesnake hyaluronidase from Crotalus durissus terrificus venom. Biochimie 2012, 94, 2740 2748, doi:10.1016/j.biochi.2012.08.014.

109. de Oliveira, S.A.; Magalhaes, M.R.; de Oliveira, L.P.; da Cunha, L.C. Identification of antinociceptive fraction of snake venom from Crotalus durissus collilineatus crotamine-negative and its acute toxicity evaluation. Toxicon 2016, 122, 145-151, doi:10.1016/j.toxicon.2016.10.008.

110. Lopes, D.M.; Junior, N.E.; Costa, P.P.; Martins, P.L.; Santos, C.F.; Carvalho, E.D.; Carvalho, M.D.; Pimenta, D.C.; Cardi, B.A.; Fonteles, M.C., et al. A new structurally atypical bradykinin-potentiating peptide isolated from Crotalus durissus cascavella venom (South American rattlesnake). Toxicon 2014, 90, 36-44, doi:10.1016/j.toxicon.2014.07.011.

111. JA, P.; V, N.; S, H.-V.; S, M.; LA, P.-S. Biochemical and Biological Characterization of a PLA2 From Crotoxin Complex of Crotalus Durissus Cumanensis. Toxicon : official journal of the International Society on Toxinology 2009, 53, doi:10.1016/j.toxicon.2009.01.021.

112. Marcussi, S.; Santos, P.R.S.; Menaldo, D.L.; Silveira, L.B.; Santos-Filho, N.; Mazzi, M.V.; da Silva, S.L.; Stábeli, R.G.; Antunes, L.M.G.; Soares, A.M. Evaluation of the genotoxicity of Crotalus durissus terrificus snake venom and its isolated toxins on human lymphocytes. Mutation research 2011, 724, 59-63, doi:10.1016/j.mrgentox.2011.06.004.

113. Shimizu, J.F.; Pereira, C.M.; Bittar, C.; Batista, M.N.; Campos, G.R.F.; da Silva, S.; Cintra, A.C.O.; Zothner, C.; Harris, M.; Sampaio, S.V., et al. Multiple effects of toxins isolated from Crotalus durissus terrificus on the hepatitis $\mathrm{C}$ virus life cycle. PLoS One 2017, 12, e0187857, doi:10.1371/journal.pone.0187857.

114. Cavalcante, W.L.; Ponce-Soto, L.A.; Marangoni, S.; Gallacci, M. Neuromuscular effects of venoms and crotoxin-like proteins from Crotalus durissus ruruima and Crotalus durissus cumanensis. Toxicon 2015, 96, 46-49, doi:10.1016/j.toxicon.2015.01.006. 
115. Cavalcante, W.L.G.; Noronha-Matos, J.B.; Timoteo, M.A.; Fontes, M.R.M.; Gallacci, M.; Correia-de-Sa, P. Neuromuscular paralysis by the basic phospholipase A2 subunit of crotoxin from Crotalus durissus terrificus snake venom needs its acid chaperone to concurrently inhibit acetylcholine release and produce muscle blockage. Toxicol Appl Pharmacol 2017, 334, 8-17, doi:10.1016/j.taap.2017.08.021.

116. Costa, C.R.C.; Belchor, M.N.; Rodrigues, C.F.B.; Toyama, D.O.; de Oliveira, M.A.; Novaes, D.P.; Toyama, M.H. Edema Induced by a Crotalus durissus terrificus Venom Serine Protease (Cdtsp 2) Involves the PAR Pathway and PKC and PLC Activation. Int J Mol Sci 2018, 19, doi:10.3390/ijms19082405.

117. de Oliveira, S.A.M.; Magalhães, M.R.; Salazar, V.C.R.; Valadares, M.C.; da Cunha, L.C. Identification of crotamine in the venom of Crotalus durissus collilineatus by three different methods. Toxicon 2015, 95, 46-51, doi:10.1016/j.toxicon.2014.12.015.

118. de Oliveira, L.A.; Ferreira, R.S., Jr.; Barraviera, B.; de Carvalho, F.C.T.; de Barros, L.C.; Dos Santos, L.D.; Pimenta, D.C. Crotalus durissus terrificus crotapotin naturally displays preferred positions for amino acid substitutions. J Venom Anim Toxins Incl Trop Dis 2017, 23, 46, doi:10.1186/s40409-017-0136-5.

119. Freitas, A.P.; Favoretto, B.C.; Clissa, P.B.; Sampaio, S.C.; Faquim-Mauro, E.L. Crotoxin Isolated from Crotalus durissus terrificus Venom Modulates the Functional Activity of Dendritic Cells via Formyl Peptide Receptors. J Immunol Res 2018, 2018, 7873257, doi:10.1155/2018/7873257.

120. Muller, V.D.; Soares, R.O.; dos Santos, N.N., Jr.; Trabuco, A.C.; Cintra, A.C.; Figueiredo, L.T.; Caliri, A.; Sampaio, S.V.; Aquino, V.H. Phospholipase A2 isolated from the venom of Crotalus durissus terrificus inactivates dengue virus and other enveloped viruses by disrupting the viral envelope. PLoS One 2014, 9 , e112351, doi:10.1371/journal.pone.0112351.

121. Vargas, L.J.; Quintana, J.C.; Pereanez, J.A.; Nunez, V.; Sanz, L.; Calvete, J. Cloning and characterization of an antibacterial L-amino acid oxidase from Crotalus durissus cumanensis venom. Toxicon 2013, 64, 1-11, doi:10.1016/j.toxicon.2012.11.027.

122. Rokyta, D.R.; Wray, K.P.; Margres, M.J. The genesis of an exceptionally lethal venom in the timber rattlesnake (Crotalus horridus) revealed through comparative venom-gland transcriptomics. BMC Genomics 2013, 14, 394, doi:10.1186/14712164-14-394.

123. Galán, J.A.; Sánchez, E.E.; Bashir, S.a.; Pérez, J.C. Characterization and identification of disintegrins in Crotalus horridus venom by liquid chromatography and tandem matrix-assisted laser desorption ionization - quadrupole ion trap timeof-flight (MALDI-QIT-TOF) mass spectrometry. Canadian Journal of Chemistry 2005, 83, 1124-1131, doi:10.1139/v05-128.

124. Borja, M.; Galan, J.A.; Cantu, E., Jr.; Zugasti-Cruz, A.; Rodriguez-Acosta, A.; Lazcano, D.; Lucena, S.; Suntravat, M.; Sanchez, Y.E.E. Morulustatin, A Disintegrin that Inhibits ADP-Induced Platelet Aggregation, Isolated from the 
Mexican Tamaulipan Rock Rattlesnake (Crotalus lepidus morulus). Rev Cient (Maracaibo) 2016, 26, 86-94.

125. Martinez-Romero, G.; Rucavado, A.; Lazcano, D.; Gutierrez, J.M.; Borja, M.; Lomonte, B.; Garza-Garcia, Y.; Zugasti-Cruz, A. Comparison of venom composition and biological activities of the subspecies Crotalus lepidus lepidus, Crotalus lepidus klauberi and Crotalus lepidus morulus from Mexico. Toxicon 2013, 71, 84-95, doi:10.1016/j.toxicon.2013.05.006.

126. Borja, M.; Lazcano, D.; Martínez-Romero, G.; Morlett, J.; Sánchez, E.; CepedaNieto, A.C.; Garza-García, Y.; Zugasti-Cruz, A. Intra-specific Variation in the Protein Composition and Proteolytic Activity of Venom of Crotalus lepidus morulus from the Northeast of Mexico. Copeia 2013, 2013, 707-716.

127. Holzer, M.; Mackessy, S.P. An aqueous endpoint assay of snake venom phospholipase A2. Toxicon 1996, 34, 1149-1155, doi:10.1016/00410101(96)00057-8.

128. KK, T.; SG, L.; J, G.; BH, B.; G, P. In Vitro Cytotoxicity of L-amino Acid Oxidase From the Venom of Crotalus Mitchellii Pyrrhus. Toxicon : official journal of the International Society on Toxinology 2017, 139, doi:10.1016/j.toxicon.2017.09.012.

129. Melendez-Martinez, D.; Macias-Rodriguez, E.; Vazquez-Briones, R.; Lopez-Vera, E.; Sandra Cruz-Perez, M.; Vargas-Caraveo, A.; Gatica-Colima, A.; Fernando Plenge-Tellechea, L. In vitro hemotoxic, alpha-neurotoxic and vasculotoxic effects of the Mexican black-tailed rattlesnake (Crotalus molossus nigrescens) venom. $J$ Venom Res 2017, 8, 1-8.

130. Rael, E.D.; Martinez, M.; Molina, O. Isolation of a fibrinolytic protease, M4, from venom of Crotalus molossus molossus (northern blacktail rattlesnake). Haemostasis 1992, 22, 41-49, doi:10.1159/000216290.

131. Borja, M.; Neri-Castro, E.; Perez-Morales, R.; Strickland, J.L.; Ponce-Lopez, R.; Parkinson, C.L.; Espinosa-Fematt, J.; Saenz-Mata, J.; Flores-Martinez, E.; Alagon, A., et al. Ontogenetic Change in the Venom of Mexican Black-Tailed Rattlesnakes (Crotalus molossus nigrescens). Toxins (Basel) 2018, 10, doi:10.3390/toxins10120501.

132. Chen, T.; Rael, E.D. Purification of M5, a fibrinolytic proteinase from Crotalus molossus molossus venom that attacks complement. Int J Biochem Cell Biol 1997, 29, 789-799.

133. Sanchez, E.E.; Soliz, L.A.; Ramirez, M.S.; Perez, J.C. Partial characterization of a basic protein from Crotalus molossus molossus (northern blacktail rattlesnake) venom and production of a monoclonal antibody. Toxicon 2001, 39, 523-537, doi:10.1016/s0041-0101(00)00165-3.

134. Sanchez, E.E.; Gonzalez, R.; Lucena, S.; Garcia, S.; Finol, H.J.; Suntravat, M.; Giron, M.E.; Fernandez, I.; Rodriguez-Acosta, A. Crotamine-like from Southern Pacific rattlesnake (Crotalus oreganus helleri) Venom acts on human leukemia (K562) cell lines and produces ultrastructural changes on mice adrenal gland. Ultrastruct Pathol 2018, 42, 116-123, doi:10.1080/01913123.2017.1422827. 
135. Martins, W.; Baldasso, P.A.; Honorio, K.M.; Maltarollo, V.G.; Ribeiro, R.I.; Carvalho, B.M.; Soares, A.M.; Calderon, L.A.; Stabeli, R.G.; Caballol, M.A., et al. A novel phospholipase A2 (D49) from the venom of the Crotalus oreganus abyssus (North American Grand canyon rattlesnake). Biomed Res Int 2014, 2014, 654170, doi:10.1155/2014/654170.

136. Da Silva, S.L.; Dias-Junior, C.A.; Baldasso, P.A.; Damico, D.C.S.; Carvalho, B.M.A.; Garanto, A.; Acosta, G.; Oliveira, E.; Albericio, F.; Soares, A.M., et al. Vascular effects and electrolyte homeostasis of the natriuretic peptide isolated from Crotalus oreganus abyssus (North American Grand Canyon rattlesnake) venom. Peptides 2012, 36, 206-212, doi:10.1016/j.peptides.2012.05.005.

137. AM, S.; B, G.; B, C.; E, C.; A, R.-A.; JC, P.; JA, G.; A, T.; EE, S. Venom Variation in Hemostasis of the Southern Pacific Rattlesnake (Crotalus Oreganus Helleri): Isolation of Hellerase. Comparative biochemistry and physiology. Toxicology \& pharmacology : CBP 2009, 149, doi:10.1016/j.cbpc.2008.08.007.

138. K, S.; EA, U.; H, S.; EC, G.; C, C.; CE, P.; I, K.; W, K.; WK, H.; GF, K., et al. Intraspecific Venom Variation in the Medically Significant Southern Pacific Rattlesnake (Crotalus Oreganus Helleri): Biodiscovery, Clinical and Evolutionary Implications. Journal of proteomics 2014, 99, doi:10.1016/j.jprot.2014.01.013.

139. Almeida, J.R.; Mendes, B.; Lancellotti, M.; Marangoni, S.; Vale, N.; Passos, O.; Ramos, M.J.; Fernandes, P.A.; Gomes, P.; Da Silva, S.L. A novel synthetic peptide inspired on Lys49 phospholipase A2 from Crotalus oreganus abyssus snake venom active against multidrug-resistant clinical isolates. Eur J Med Chem 2018, 149, 248256, doi:10.1016/j.ejmech.2018.02.055.

140. Marquez, J.; Parra, V.; Suntravat, M.; Sanchez, E.E. Purification and characterization of cysteine rich-secretory proteins (CRiSPs) from the venom of the Southern Pacific rattlesnake (Crotalus oreganus helleri): Their role on blood and lymphatic endothelial cell permeability. Toxicon 2018, 150, 315-334.

141. Hamako, J.; Suzuki, Y.; Hayashi, N.; Kimura, M.; Ozeki, Y.; Hashimoto, K.; Matsui, T. Amino acid sequence and characterization of C-type lectin purified from the snake venom of Crotalus ruber. Comp Biochem Physiol B Biochem Mol Biol 2007, 146, 299-306, doi:10.1016/j.cbpb.2006.11.022.

142. Mori, N.; Sugihara, H. Comparative study of two arginine ester hydrolases, E-I and E-II from the venom of Crotalus ruber ruber (red rattlesnake). Comp Biochem Physiol B 1989, 92, 537-547, doi:10.1016/0305-0491(89)90129-6.

143. Straight, R.C.; Glenn, J.L.; Wolt, T.B.; Wolfe, M.C. North-south regional variation in phospholipase A activity in the venom of Crotalus ruber. Comp Biochem Physiol B 1992, 103, 635-639, doi:10.1016/0305-0491(92)90382-2.

144. Mori, N.; Nikai, T.; Sugihara, H.; Tu, A.T. Biochemical characterization of hemorrhagic toxins with fibrinogenase activity isolated from Crotalus ruber ruber venom. Arch Biochem Biophys 1987, 253, 108-121, doi:10.1016/00039861(87)90643-6.

145. Mori, N.; Nikai, T.; Sugihara, H. Phosphodiesterase from the venom of Crotalus ruber ruber. Int J Biochem 1987, 19, 115-119. 
146. Mori, N.; Sugihara, H. Characterization of kallikrein-like enzyme from Crotalus ruber ruber (red rattlesnake) venom. Int J Biochem 1989, 21, 83-90.

147. Sanchez, E.E.; Galan, J.A.; Powell, R.L.; Reyes, S.R.; Soto, J.G.; Russell, W.K.; Russell, D.H.; Perez, J.C. Disintegrin, hemorrhagic, and proteolytic activities of Mohave rattlesnake, Crotalus scutulatus scutulatus venoms lacking Mojave toxin. Comp Biochem Physiol C Toxicol Pharmacol 2005, 141, 124-132, doi:10.1016/j.cca.2005.04.001.

148. Borja, M.; Castañeda, G.; Espinosa, J.; Neri, E.; Carbajal, A.; Clement, H.; García, O.; Alagon, A. Mojave Rattlesnake (Crotalus scutulatus scutulatus) with Type B Venom from Mexico. Copeia 2014, 2014, 7-13, doi:10.1643/OT-12-041.

149. Massey, D.J.; Calvete, J.J.; Sanchez, E.E.; Sanz, L.; Richards, K.; Curtis, R.; Boesen, K. Venom variability and envenoming severity outcomes of the Crotalus scutulatus scutulatus (Mojave rattlesnake) from Southern Arizona. J Proteomics 2012, 75, 2576-2587, doi:10.1016/j.jprot.2012.02.035.

150. Hinson, M.W.; Childs, C.; Johnson, B.D.; Sifford, D.H. Concanavalin A-Binding Enzymes of Crotalus scutulatus scutulatus Venom. Journal of the Arkansas Academy of Science 1985, 39, 50-54.

151. Ho, C.L.; Lee, C.Y. Presynaptic actions of Mojave toxin isolated from Mojave rattlesnake (crotalus scutulatus) venom. Toxicon 1981, 19, 889-892, doi:10.1016/0041-0101(81)90086-6.

152. Modahl, C.M.; Mackessy, S.P. Full-Length Venom Protein cDNA Sequences from Venom-Derived mRNA: Exploring Compositional Variation and Adaptive Multigene Evolution. PLoS Negl Trop Dis 2016, 10, e0004587, doi:10.1371/journal.pntd.0004587.

153. Durban, J.; Sanz, L.; Trevisan-Silva, D.; Neri-Castro, E.; Alagon, A.; Calvete, J.J. Integrated Venomics and Venom Gland Transcriptome Analysis of Juvenile and Adult Mexican Rattlesnakes Crotalus simus, C. tzabcan, and C. culminatus Revealed miRNA-modulated Ontogenetic Shifts. J Proteome Res 2017, 16, 33703390, doi:10.1021/acs.jproteome.7b00414.

154. Nielsen, V.G.; Boyer, L.V.; Redford, D.T.; Ford, P. Thrombelastographic characterization of the thrombin-like activity of Crotalus simus and Bothrops asper venoms. Blood Coagul Fibrinolysis 2017, 28, 211-217, doi:10.1097/mbc.0000000000000577.

155. Weinstein, S.A.; Smith, L.A. Preliminary fractionation of tiger rattlesnake (Crotalus tigris) venom. Toxicon 1990, 28, 1447-1455, doi:10.1016/0041-0101(90)90158-4.

156. Minton, S.A.; Weinstein, S.A. Protease activity and lethal toxicity of venoms from some little known rattlesnakes. Toxicon 1984, 22, 828-830, doi:10.1016/00410101(84)90169-7.

157. Powell, R.L.; Lieb, C.S.; Rael, E.D. Identification of a neurotoxic venom component in the Tiger rattlesnake, Crotalus tigris. Journal of herpetology 2004, 38, 149-152. 
158. Kaiser, II; Aird, S.D. A crotoxin homolog from the venom of the Uracoan rattlesnake (Crotalus vegrandis). Toxicon 1987, 25, 1113-1120, doi:10.1016/00410101(87)90268-6.

159. Scannone, H.R.; Rodriguez, O.G.; Lancini, A.R. Enzymatic activities and other characteristics of Crotalus vegrandis snake venom. In Toxins, Rosenberg, P., Ed. Pergamon: 1978; pp. 223-229.

160. Moore, S.W.; Bhat, V.K.; Flatt, P.R.; Gault, V.A.; McClean, S. Isolation and characterisation of insulin-releasing compounds from Crotalus adamanteus, Crotalus vegrandis and Bitis nasicornis venom. Toxicon 2015, 101, 48-54, doi:10.1016/j.toxicon.2015.05.002.

161. Giron, M.; Pinto, A.; Finol, H.J.; Aguilar, I.; Rodriguez-Acosta, A. Kidney structural and ultrastructural pathological changes induced by uracoan rattlesnake (Crotalus vegrandis Klauber 1941) venom. J Submicrosc Cytol Pathol 2002, 34, 447-459.

162. Aguilar, I.; Giron, M.E.; Rodriguez-Acosta, A. Purification and characterisation of a haemorrhagic fraction from the venom of the Uracoan rattlesnake Crotalus vegrandis. Biochim Biophys Acta 2001, 1548, 57-65, doi:10.1016/s01674838(01)00217-5.

163. Adade, C.; Fernandes Anne Cristine, S.; Carvalho Ana Lúcia, O.; Zingali, R.; Souto-Padrón, T. 44. Leishmanicidal Effects of a Phospholipase A2 Isolated from Crotalus viridis viridis Snake Venom. Toxicon 2012, 60, 117, doi:10.1016/j.toxicon.2012.04.045.

164. Adade, C.M.; Cons, B.L.; Melo, P.A.; Souto-Padron, T. Effect of Crotalus viridis viridis snake venom on the ultrastructure and intracellular survival of Trypanosoma cruzi. Parasitology 2011, 138, 46-58, doi:10.1017/s0031182010000958.

165. Zancolli, G.; Baker, T.G.; Barlow, A.; Bradley, R.K.; Calvete, J.J.; Carter, K.C.; de Jager, K.; Owens, J.B.; Price, J.F.; Sanz, L., et al. Is Hybridization a Source of Adaptive Venom Variation in Rattlesnakes? A Test, Using a Crotalus scutulatus $\times$ viridis Hybrid Zone in Southwestern New Mexico. Toxins 2016, 8, doi:10.3390/toxins8060188.

166. NH, T.; G, P. A Comparative Study of the Biological Activities of Rattlesnake (Genera Crotalus and Sistrurus) Venoms. Comparative biochemistry and physiology. C, Comparative pharmacology and toxicology 1991, 98, doi:10.1016/0742-8413(91)90233-j.

167. Pahari, S.; Mackessy, S.P.; Kini, R.M. The venom gland transcriptome of the Desert Massasauga rattlesnake (Sistrurus catenatus edwardsii): towards an understanding of venom composition among advanced snakes (Superfamily Colubroidea). BMC molecular biology 2007, 8, 115, doi:10.1186/1471-2199-8-115.

168. Doley, R.; Pahari, S.; Mackessy, S.P.; Kini, R.M. Accelerated exchange of exon segments in Viperid three-finger toxin genes (Sistrurus catenatus edwardsii; Desert Massasauga). BMC Evol Biol 2008, 8, 196, doi:10.1186/1471-2148-8-196.

169. Lisle Gibbs, H.; Chiucchi, J.E. Deconstructing a complex molecular phenotype: population-level variation in individual venom proteins in Eastern Massasauga 
Rattlesnakes (Sistrurus c. catenatus). J Mol Evol 2011, 72, 383-397, doi:10.1007/s00239-011-9437-4.

170. Sunagar, K.; Jackson, T.N.; Undheim, E.A.; Ali, S.A.; Antunes, A.; Fry, B.G. Three-fingered RAVERs: Rapid Accumulation of Variations in Exposed Residues of snake venom toxins. Toxins (Basel) 2013, 5, 2172-2208, doi:10.3390/toxins5112172.

171. Chapeaurouge, A.; Reza, M.A.; Mackessy, S.P.; Carvalho, P.C.; Valente, R.H.; Teixeira-Ferreira, A.; Perales, J.; Lin, Q.; Kini, R.M. Interrogating the Venom of the Viperid Snake Sistrurus catenatus edwardsii by a Combined Approach of Electrospray and MALDI Mass Spectrometry. PLoS One 2015, 10, e0092091, doi:10.1371/journal.pone.0092091.

172. Gibbs, H.L.; Sanz, L.; Calvete, J.J. Snake population venomics: proteomics-based analyses of individual variation reveals significant gene regulation effects on venom protein expression in Sistrurus rattlesnakes. J Mol Evol 2009, 68, 113-125, doi:10.1007/s00239-008-9186-1.

173. Juarez, P.; Sanz, L.; Calvete, J.J. Snake venomics: characterization of protein families in Sistrurus barbouri venom by cysteine mapping, $\mathrm{N}$-terminal sequencing, and tandem mass spectrometry analysis. Proteomics 2004, 4, 327-338, doi:10.1002/pmic.200300628.

174. Gibbs, H.L.; Sanz, L.; Chiucchi, J.E.; Farrell, T.M.; Calvete, J.J. Proteomic analysis of ontogenetic and diet-related changes in venom composition of juvenile and adult Dusky Pigmy rattlesnakes (Sistrurus miliarius barbouri). J Proteomics 2011, 74, 2169-2179, doi:10.1016/j.jprot.2011.06.013.

175. Sanz, L.; Gibbs, H.L.; Mackessy, S.P.; Calvete, J.J. Venom Proteomes of Closely Related Sistrurus Rattlesnakes with Divergent Diets. Journal of Proteome Research 2006, 5, 2098-2112, doi:10.1021/pr0602500.

176. Carstairs, S.D.; Kreshak, A.A.; Tanen, D.A. Crotaline Fab antivenom reverses platelet dysfunction induced by Crotalus scutulatus venom: an in vitro study. Acad Emerg Med 2013, 20, 522-525, doi:10.1111/acem.12135.

177. DJ, S.; DP, B. Snake Venom Toxins. I. Preliminary Studies on the Separation of Toxins of Elapidae Venoms. Toxicon : official journal of the International Society on Toxinology 1970, 8, doi:10.1016/0041-0101(70)90203-5.

178. Laustsen, A.H. Toxin synergism in snake venoms. Toxin Reviews 2016, 35, 165170.

179. Lomeo, R.d.S.; Gonçalves, A.P.d.F.; Silva, C.N.d.; de Paula, A.T.; Costa Santos, D.O.; Fortes-Dias, C.; Gomes, D.A.; de Lima, M.E. Crotoxin from Crotalus durissus terrificus snake venom induces the release of glutamate from cerebrocortical synaptosomes via N and P/Q calcium channels. Toxicon 2014, 85, 516, doi:10.1016/j.toxicon.2014.04.008.

180. Faure, G.; Xu, H.; Saul, F.A. Crystal structure of crotoxin reveals key residues involved in the stability and toxicity of this potent heterodimeric $\beta$-neurotoxin. Journal of Molecular Biology 2011, 412, 176-191, doi:10.1016/j.jmb.2011.07.027. 
181. CC, G.; LC, L.; S, M.; P, T.; O, A.d.P. Proteolytic, Edematogenic and Myotoxic Activities of a Hemorrhagic Metalloproteinase Isolated From Bothrops Alternatus Venom. Toxicon : official journal of the International Society on Toxinology $\mathbf{2 0 0 5}$, 46, doi:10.1016/j.toxicon.2005.06.019.

182. ME, G.D.; OC, A.; S, H.-V.; D, M.-d.-S.; S, M.; SL, M.; GP, T.; LC, L.; LA, P.-S. Isolation and Functional Characterization of a New Acidic PLA(2) Ba SpII RP4 of the Bothrops Alternatus Snake Venom From Argentina. Toxicon : official journal of the International Society on Toxinology 2010, 56, doi:10.1016/j.toxicon.2010.02.031.

183. S, B.; CC, G.; ME, G.D.; LA, P.-S.; E, B.d.K.J.; O, A.; LC, L. Synergism Between Baltergin Metalloproteinase and Ba SPII RP4 PLA2 From Bothrops Alternatus Venom on Skeletal Muscle (C2C12) Cells. Toxicon : official journal of the International Society on Toxinology 2012, 59, doi:10.1016/j.toxicon.2011.11.007.

184. S, B.; ME, G.-D.; C, G.; AC, V.d.V.; O, A.; Y, A.; B, L.; JM, G.; L, L. Phospholipase A(2) Enhances the Endothelial Cell Detachment Effect of a Snake Venom Metalloproteinase in the Absence of Catalysis. Chemico-biological interactions 2015, 240, doi:10.1016/j.cbi.2015.08.002.

185. J, Š.; J, O.; I, K. Understanding the Molecular Mechanism Underlying the Presynaptic Toxicity of Secreted Phospholipases A(2): An Update. Toxicon : official journal of the International Society on Toxinology 2014, 89, doi:10.1016/j.toxicon.2014.06.019.

186. Higuchi, S.; Murayama, N.; Saguchi, K.; Ohi, H.; Fujita, Y.; Camargo, A.C.; Ogawa, T.; Deshimaru, M.; Ohno, M. Bradykinin-potentiating peptides and C-type natriuretic peptides from snake venom. Immunopharmacology 1999, 44, 129-135.

187. Murayama, N.; Hayashi, M.A.; Ohi, H.; Ferreira, L.A.; Hermann, V.V.; Saito, H.; Fujita, Y.; Higuchi, S.; Fernandes, B.L.; Yamane, T., et al. Cloning and sequence analysis of a Bothrops jararaca cDNA encoding a precursor of seven bradykininpotentiating peptides and a C-type natriuretic peptide. Proceedings of the National Academy of Sciences of the United States of America 1997, 94, 1189-1193, doi:10.1073/pnas.94.4.1189.

188. Rebello Horta, C.C.; Chatzaki, M.; Rezende, B.A.; Magalhaes Bde, F.; Duarte, C.G.; Felicori, L.F.; Ribeiro Oliveira-Mendes, B.B.; do Carmo, A.O.; ChavezOlortegui, C.; Kalapothakis, E. Cardiovascular-Active Venom Toxins: An Overview. Curr Med Chem 2016, 23, 603-622, doi:10.2174/0929867323666160126142837.

189. Cushman, D.W.; Ondetti, M.A. History of the design of captopril and related inhibitors of angiotensin converting enzyme. Hypertension 1991, 17, 589-592, doi:10.1161/01.hyp.17.4.589.

190. Y, Z.; W, X.; B, M.; K, H.; M, S.; N, Z.; Y, Z.; Y, W.; Y, D.; Y, L. Isolation and Characterisation of a Kallikrein-Like Enzyme From Agkistrodon Halys Pallas Snake Venom. Journal of the science of food and agriculture 2012, 92, doi:10.1002/jsfa.4733. 
191. MA, H.; AC, C. The Bradykinin-potentiating Peptides From Venom Gland and Brain of Bothrops Jararaca Contain Highly Site Specific Inhibitors of the Somatic Angiotensin-Converting Enzyme. Toxicon : official journal of the International Society on Toxinology 2005, 45, doi:10.1016/j.toxicon.2005.02.017.

192. P, B.; E, G.; OB, H. Comparative Action of Various Kininogenases on Crude Horse Plasma Substrates. Biochemical pharmacology 1970, 19, doi:10.1016/00062952(70)90306-0.

193. LF, F.; CT, S.; DT, V.; A, M.; AP, A.; S, F.; M, R.; CR, D.; EF, S. Kallikrein-like Proteinase From Bushmaster Snake Venom. Protein expression and purification 2003, 30, doi:10.1016/s1046-5928(03)00053-6.

194. Soto, J.G.; White, S.A.; Reyes, S.R.; Regalado, R.; Sanchez, E.E.; Perez, J.C. Molecular evolution of PIII-SVMP and RGD disintegrin genes from the genus Crotalus. Gene 2007, 389, 66-72, doi:10.1016/j.gene.2006.09.020.

195. Calvete, J.J.; Moreno-Murciano, M.P.; Theakston, R.D.; Kisiel, D.G.; Marcinkiewicz, C. Snake venom disintegrins: novel dimeric disintegrins and structural diversification by disulphide bond engineering. Biochem J 2003, 372, 725-734, doi:10.1042/bj20021739.

196. Markland, F.S.; Swenson, S. Snake venom metalloproteinases. Toxicon 2013, 62, 318, doi:10.1016/j.toxicon.2012.09.004.

197. EN, B.; JD, S.; JB, B.; SL, G.; JW, F. Interaction of Hemorrhagic Metalloproteinases With Human Alpha 2-macroglobulin. Biochemistry 1990, 29, doi:10.1021/bi00456a032.

198. Calvete, J.J.; Marcinkiewicz, C.; Monleon, D.; Esteve, V.; Celda, B.; Juarez, P.; Sanz, L. Snake venom disintegrins: evolution of structure and function. Toxicon 2005, 45, 1063-1074, doi:10.1016/j.toxicon.2005.02.024.

199. Yee, K.T.; Pitts, M.; Tongyoo, P.; Rojnuckarin, P.; Wilkinson, M.C. Snake Venom Metalloproteinases and Their Peptide Inhibitors from Myanmar Russell's Viper Venom. In Toxins (Basel), 2017; Vol. 9.

200. Sunagar, K.; Fry, B.G.; Jackson, T.N.W.; Casewell, N.R.; Undheim, E.A.B.; Vidal, N.; Ali, S.A.; King, G.F.; Vasudevan, K.; Vasconcelos, V., et al. Molecular Evolution of Vertebrate Neurotrophins: Co-Option of the Highly Conserved Nerve Growth Factor Gene into the Advanced Snake Venom Arsenalf. PLOS ONE 2013, 8, e81827, doi:10.1371/journal.pone.0081827.

201. Wijeyewickrema, L.C.; Gardiner, E.E.; Gladigau, E.L.; Berndt, M.C.; Andrews, R.K. Nerve growth factor inhibits metalloproteinase-disintegrins and blocks ectodomain shedding of platelet glycoprotein VI. J Biol Chem 2010, 285, 11793 11799, doi:10.1074/jbc.M110.100479.

202. JM, F.; YA, B. Genetic Evidence for Cell Death Mediated by Nerve Growth Factor and the Neurotrophin Receptor p75 in the Developing Mouse Retina and Spinal Cord. Development (Cambridge, England) 1999, 126.

203. JM, F.; A, R.-T.; YA, B. Induction of Cell Death by Endogenous Nerve Growth Factor Through Its p75 Receptor. Nature 1996, 383, doi:10.1038/383166a0. 
204. KS, G.; DK, J.; KB, R.; K, K. Snake Venom Hyaluronidase: An Evidence for Isoforms and Extracellular Matrix Degradation. Molecular and cellular biochemistry 2002, 240, doi:10.1023/a:1020651607164.

205. V, P.; PC, K. Mast Cell Tryptase: A Review of Its Physiology and Clinical Significance. Anaesthesia 2004, 59, doi:10.1111/j.1365-2044.2004.03757.x.

206. Nunes Edos, S.; de Souza, M.A.; Vaz, A.F.; Santana, G.M.; Gomes, F.S.; Coelho, L.C.; Paiva, P.M.; da Silva, R.M.; Silva-Lucca, R.A.; Oliva, M.L., et al. Purification of a lectin with antibacterial activity from Bothrops leucurus snake venom. Comp Biochem Physiol B Biochem Mol Biol 2011, 159, 57-63, doi:10.1016/j.cbpb.2011.02.001.

207. S, N.; MA, M.; M, K.; GJ, S. Disintegrins and Other Naturally Occurring Antagonists of Platelet Fibrinogen Receptors. Seminars in hematology 1994, 31. 